\title{
Factors determining subsidence in urbanized floodplains: evidence from MT-InSAR in Seville (southern Spain)
}

\author{
Ana Ruiz-Constán, ${ }^{1 *}$ (D) Antonio M. Ruiz-Armenteros, ${ }^{2,3,4}$ Jesús Galindo-Zaldívar, ${ }^{1,5}$ Francisco Lamas-Fernández, ${ }^{6}$ \\ Joaquim João Sousa, ${ }^{7}$ Carlos Sanz de Galdeano, ${ }^{5}$ Antonio Pedrera, ${ }^{8}$ Sergio Martos-Rosillo, ${ }^{8}$ Miguel Caro Cuenca, ${ }^{9}$ \\ J. Manuel Delgado, ${ }^{3,10}$ Ramon F. Hanssen ${ }^{11}$ and Antonio J. Gil ${ }^{2,3,4}$ \\ 1 Departamento de Geodinámica, Universidad de Granada, Granada, Spain \\ 2 Departamento de Ingeniería Cartográfica, Geodésica y Fotogrametría, Universidad de Jaén, Jaén, Spain \\ 3 Grupo de Investigación Microgeodesia Jaén, Universidad de Jaén, Jaén, Spain \\ ${ }^{4}$ Centro de Estudios Avanzados en Ciencias de la Tierra (CEACTierra), Universidad de Jaén, Jaén, Spain \\ ${ }^{5}$ Instituto Andaluz de Ciencias de la Tierra, CSIC-Universidad de Granada, Granada, Spain \\ ${ }^{6}$ Departamento de Ingeniería Civil, Universidad de Granada, Granada, Spain \\ 7 Universidade de Trás-Os-Montes e Alto Douro, INESC-TEC (fomerly INESC Porto), Vila Real, Portugal \\ 8 Instituto Geológico y Minero de España, Madrid, Spain \\ ${ }^{9}$ Department of Radar Technology, TNO, The Netherlands \\ ${ }^{10}$ Progressive Systems Srl, Rome, Italy \\ 11 Department of Geoscience and Remote Sensing, Delft University of Technology, Delft, The Netherlands
}

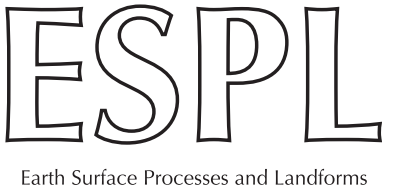

ABSTRACT: Major rivers have traditionally been linked with important human settlements throughout history. The growth of cities over recent river deposits makes necessary the use of multidisciplinary approaches to characterize the evolution of drainage networks in urbanized areas. Since under-consolidated fluvial sediments are especially sensitive to compaction, their spatial distribution, thickness, and mechanical behavior must be studied. Here, we report on subsidence in the city of Seville (Southern Spain) between 2003 and 2010, through the analysis of the results obtained with the Multi-Temporal InSAR (MT-InSAR) technique. In addition, the temporal evolution of the subsidence is correlated with the rainfall, the river water column and the piezometric level. Finally, we characterize the geotechnical parameters of the fluvial sediments and calculate the theoretical settlement in the most representative sectors. Deformation maps clearly indicate that the spatial extent of subsidence is controlled by the distribution of under-consolidated fine-grained fluvial sediments at heights comprised in the range of river level variation. This is clearly evident at the western margin of the river and the surroundings of its tributaries, and differs from rainfall results as consequence of the anthropic regulation of the river. On the other hand, this influence is not detected at the eastern margin due to the shallow presence of coarse-grain consolidated sediments of different terrace levels. The derived results prove valuable for implementing urban planning strategies, and the InSAR technique can therefore be considered as a complementary tool to help unravel the subsidence tendency of cities located over under-consolidated fluvial deposits. Copyright @ 2017 John Wiley \& Sons, Ltd.

KEYWORDS: historic town; fluvial system; InSAR; subsidence; SW Spain

\section{Introduction}

The interaction between human activity and natural system dynamics, while inherent to civilization, has greatly conditioned the evolution of landscapes since immemorial times (Thomas, 1956; Braga and Gervasoni, 1989). Seen the other way round, the natural features and processes of a given place play an important role in the development of society. Relationships between villages and rivers have been widely documented (Strahler, 1956; Wolman, 1967; Gregory, 1977, 1995; Bledsoe and Watson, 2001; Hooke, 2006). Human demands for fresh water, fertile soil or vias of communication/transport traditionally link fluvial systems with important human settlements around the world (Paris, Cairo, Shanghai, Rome, Minneapolis, etc.).

The use of multi-temporal SAR interferometry has made a breakthrough in the spatial and temporal monitoring of surface vertical displacements (natural or anthropogenic) over wide areas, at a higher resolution and with a lower cost than other conventional techniques (Amelung et al., 1999; Tomás et al., 2014). This methodology has been applied to diverse geological contexts usually interconnected with human activity or human settlements such as: seismicity (Funning et al., 2005; Peyret et al., 2008; Bell et al., 2012); overexploitation of 
aquifers (Tomás et al., 2011; Boni et al., 2015; Ruiz-Constán et al., 2016); oil extraction (Zhang et al., 2015); delta dynamics (Mazzotti et al., 2009; Higgins et al., 2014); or urbanization (Stramondo et al., 2008) among others.

Under-consolidated fine-grained sediments (silt and clays) are especially sensitive to compaction (Holzer, 1984). Their thickness, age and distribution highly conditions the amount and location of subsiding sectors, the most common triggering factor being the groundwater depletion (Galloway and Hoffmann, 2007; Becker and Sultan, 2009; Davila-Hernandez et al., 2014). Most attention has been paid to the overdrafted aquifer systems and their impact on urbanization (Bell et al., 2008; Ezquerro et al., 2014). However, other contexts such as water level evolution of rivers, natural or due to anthropic regulation, should also be considered.

In southern Spain, the convenient conditions provided by the Guadalquivir River favored the foundation of the prehistoric Spal (primary name of Seville) around the 8th century BC, as well as subsequent settlements of different civilizations (Barral, 2004; Borja and Barral, 2005). The expansion of the urban area and recurrent floods - together with factors such as climate, tectonic activity, sea level, etc. - induced the development of various hydraulic actions (bridges, embankments, channels, flood protections) along the river, conditioning its channel distribution and dynamics (Vanney, 1970; Menanteau, 1982; Diaz del Olmo et al., 1989; Borja Barrera, 1995).

The present study evaluates the influence of underconsolidated fluvial sediments on the differential subsidence affecting Seville (southern Spain) and the effect of the anthropic regulation of the Guadalquivir River flow rate. We report on subsidence in the city through an analysis of results obtained with the Multi-Temporal InSAR (MT-InSAR) technique. The dataset consists of 19 Envisat ASAR scenes acquired from February 2003 to September 2010. The maps obtained of relative ground-surface change were matched up with the spatial evolution of the Guadalquivir River during the Holocene, previously established through sedimentological, geomorphological, and archaeological studies (Barral and Borja, 2002; Barral, 2004, 2009). In addition, we estimated the trend of the river water column, the rainfall and the accumulated rainfall curve, in order to compare its temporal evolution with the estimated subsidence. Finally, we were able to characterize the geotechnical parameters of the fluvial sediments through the analysis of 36 boreholes distributed over the highest and lowest subsiding sectors, and offer a discussion of these results.

\section{Study area}

The Guadalquivir River (Figure 1) is the fifth longest river $(657 \mathrm{~km})$ in the Iberian Peninsula and the most important one in southern Spain in terms of flow rate and watershed surface $\left(46000 \mathrm{~km}^{2}\right)$. Its fluvial regime is irregular and torrential (Menanteau and Vanney, 1985) and the river watershed has a Mediterranean climate, with an average annual precipitation of $600-650 \mathrm{~mm}$ and an average annual temperature of $17-$ $18^{\circ} \mathrm{C}$ (Durán-Valsero et al., 2003). The lower section of the river, the one comprised between Seville and the Guadalquivir river mouth, is constituted by a low slope estuary where the main channel is locally subdivided into several branches that converge again in a single channel before flowing out into the Atlantic Ocean. Tidal influence is relevant up to a few kilometers south of Seville.

The average flow of the Guadalquivir River before human regulation of the channel was $200 \mathrm{~m}^{3} \mathrm{~s}^{-1}$. However, during the dry season it could decrease to $10 \mathrm{~m}^{3} \mathrm{~s}^{-1}$, while during river flooding periods it could reach $5000 \mathrm{~m}^{3} \mathrm{~s}^{-1}$ (5 year recurrence

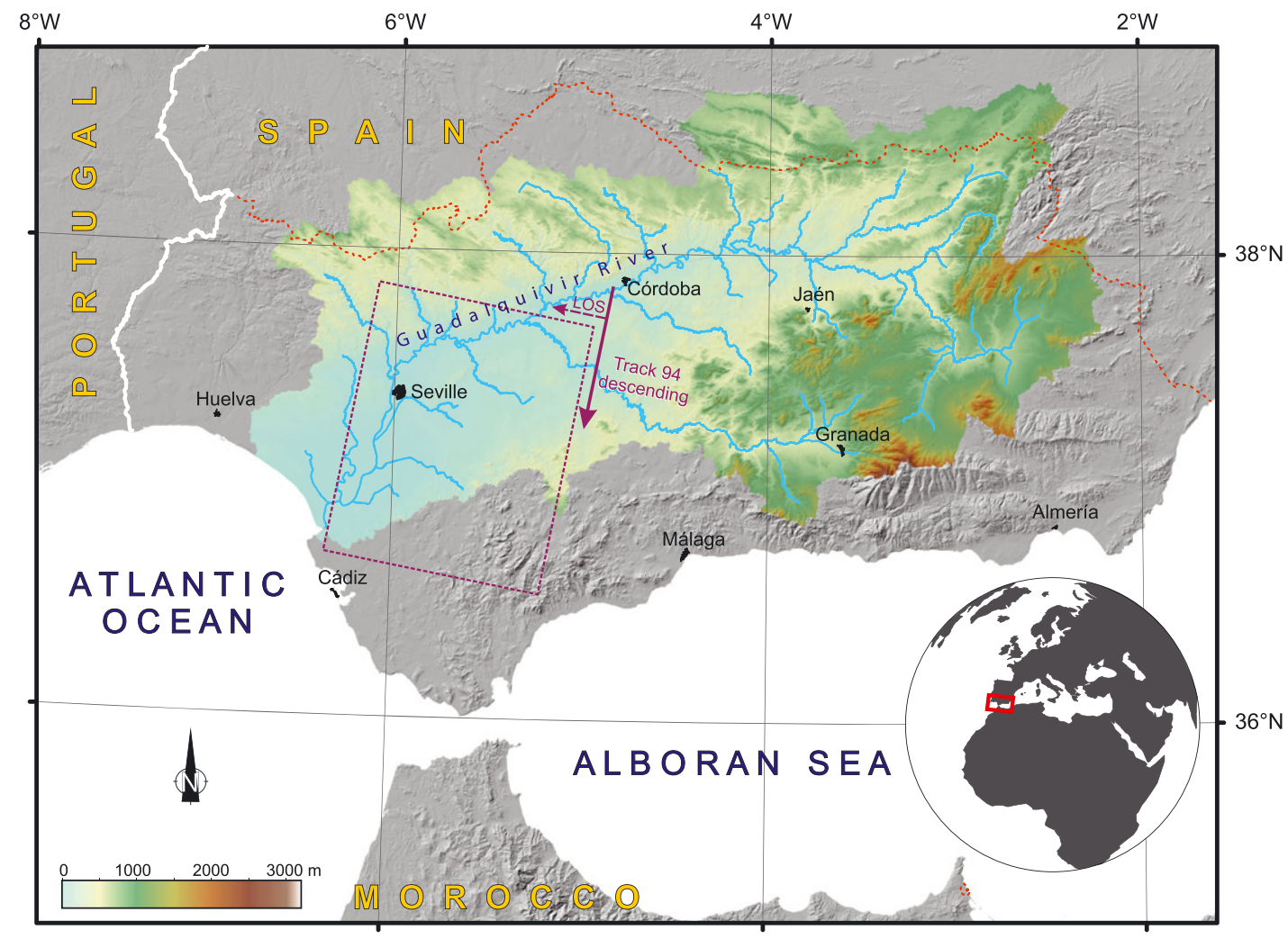

Figure 1. Location map of Seville and the Guadalquivir Basin. The SAR data coverage used in the study is indicated by a purple rotated box, the arrow showing the descending satellite pass (track). The radar is most sensitive to deformation in the radar line-of-sight (LOS), dashed arrow. The white line indicates the country border between Spain and Portugal, while the red line marks the regional boundary of Andalusia. [Colour figure can be viewed at wileyonlinelibrary.com] 
period) or $9000 \mathrm{~m}^{3} \mathrm{~s}^{-1}$ (100 year recurrence period). During these extraordinary flow increases, the water table rises to within a range of approximately $2.5-5 \mathrm{~m}$ (del Moral Ituarte, 1997). These features have produced recurrent floods (Vanney, 1970) and the inundation of important historical cities located along the river lower course (e.g. Córdoba and Seville). For example, 56 floods were documented in Seville between the 15th and 18th centuries (Borja Palomo, 1878; Uribelarrea and Benito, 2008).

The city of Seville and its peri-urban area lie in the Guadalquivir foreland basin, which was filled by Neogene and Quaternary sediments during the development of the Betic Cordillera. The city mainly occupies the present day alluvial floodplain of the Guadalquivir River and several late Pleistocene-Holocene terrace levels (Baena Escudero, 1993). The high permeability sediments of the alluvial floodplain are constituted of silts and clays that generally evolve to sands and gravels at the bottom (de Torres, 1973; Roldán García and Borrero Domínguez, 1988). The aquifer detritic succession ends at the boundary with an aquitard blue marl formation (Borja Barrera, 1992) that was deposited during the late Miocene in a deep marine context. Alluvial deposits in the left bank of the river show a greater extension than those of the right bank, a consequence of the migration of the main river channel toward the west-northwest (Goy et al., 1994). This displacement has also conditioned its incision in older deposits, favoring the existence of 14 terrace levels (Baena Escudero, 1993; Baena and Díaz del Olmo, 1994). Those located at the study area correspond with the so-called T12
(26-29 m.a.s.l; Middle-Early Pleistocene), T13 (13-14 m.a.s.I.; Late Pleistocene-Early Holocene) and T14 (several terrace levels at heights lower than 13 m.a.s.l.; Late Holocene).

Two main reliefs stand out in the study sector (Figure 2). The Alcores realm constitutes the source area of the main tributaries (Tamarguillo, Tagarete, Guadaira) arriving at the city from the east and is formed by Quaternary consolidated alluvial sediments. Westward of Seville, the Aljarafe realm comprises a sequence of 10-60 m thick Neogene coastal rocks and fluvial Quaternary sediments. Flux direction at the Aljarafe area is mainly from north to south, but there are important east-west deflections associated with the lateral flux towards the Guadalquivir River (Durán-Valsero et al., 2003), as occurs in the Alcores sector (Figure 2).

\section{Human changes to the river channel}

Throughout human history, numerous interventions have been undertaken in the city of Seville for two purposes: (i) to mitigate the floods; and (ii) to preserve the river as an inland waterway. The ancient Roman village of Hispalis was founded in the 2nd century BC at a topographic realm (T14 lower terraces complex; Baena Escudero, 1993), located $6 \mathrm{~m}$ above the floodplain at that time and $8 \mathrm{~m}$ above the present-day sea level (Barral, 2004). This place was near the junction between the main channel of the Guadalquivir River at Roman times (Collantes de Terán, 1977; Díaz del Olmo and Borja, 1991) and the Tagarete tributary (Figure 2). In the 8th century, after

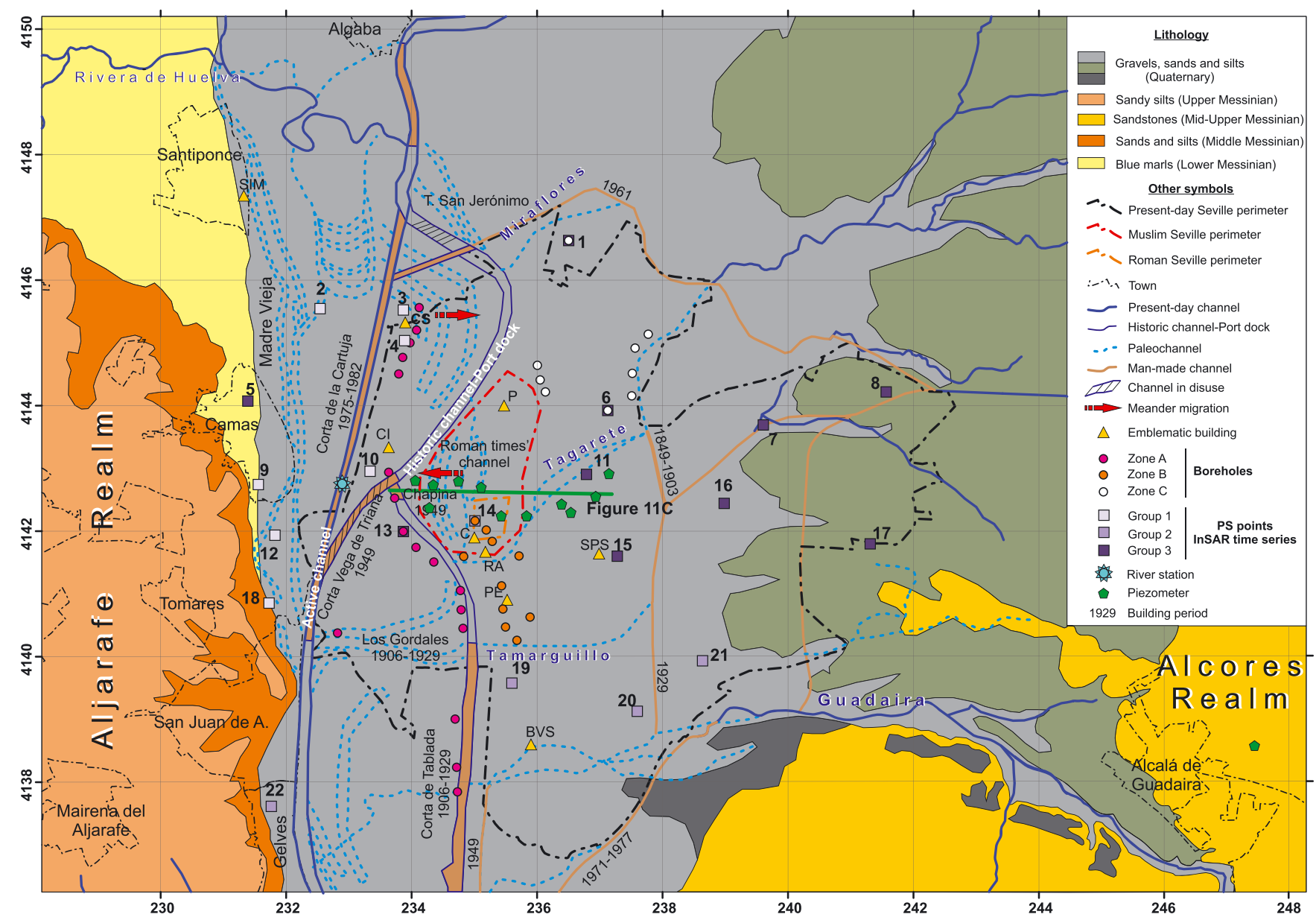

Figure 2. Geological map of Seville; UTM coordinates in km, ETRS89 zone 30 N. Main changes in the drainage network are indicated. Several emblematic places are marked for reference: BVS- Benito Villamarín Stadium; C-Cathedral; Cl- Cartuja Island; CS-Cartuja Stadium; P- Parliament; PE- Plaza de España; RA- Real Alcázar; SPS- Sanchez Pizjuán Stadium; SIM- San Isidoro Monastery. The green line corresponds to the section in Figure 11. [Colour figure can be viewed at wileyonlinelibrary.com] 
successive settlements of different peoples and cultures, the Muslims were established in Seville - then called Isbiliya and considerably broadened the city towards the west, most probably through the westward migration of the river channel (Barral and Borja, 2002). During the 11th and 12th centuries they also accomplished the construction of walls with a doubly defensive aim, to hinder access to enemies and as a barrier to the recurrent floods of the Guadalquivir River.

During the 19th century, the walls were partially destroyed and another period of inundation started, not only caused by the Guadalquivir River but also by the Tagarete, Tamargillo and Guadaira tributaries. At that time, the challenge was to extend the city eastward; this was done at the expense of the desiccation of the last stretch of the Tagarete tributary and its southward deviation to the Tamarguillo. Since then, many meanders have been rectified through the successive building of artificial rectilinear channels, locally called 'cortas', to reduce the natural itinerary of the river (from $120 \mathrm{~km}$ in the 19th century to just $80 \mathrm{~km}$ nowadays). The object was to avoid locations with low vertical water section, thereby increasing the velocity of the current and decreasing the sedimentation rate. In the first third of the 20th century, all the flow coming from the east (Tagarete and Tamarguillo) was transferred towards the southern part of the city, into the Guadaira River. When this measure later proved to be insufficient, the last stretch of the Guadaira River was diverted southwards. At present, the active channel of the river remains in the western part of the city, while the historical channel has become the port's dock.

\section{InSAR technique}

In this section, the interferometric processing methodology used in this work is presented. First we show the SAR dataset that supports the measured ground movements. We then introduce some basic concepts of Differential Interferometric Synthetic Aperture Radar (DInSAR) and a review of the MTInSAR algorithms used in this study.

\section{SAR dataset}

To estimate ground motion, we used Multi-Temporal spaceborne SAR interferometry on 19 Envisat ASAR C-band images ( $5.7 \mathrm{~cm}$ wavelength), acquired between February 2003 and September 2010 (Tables I and II), along descending orbits, with an incidence angle ranging from $19.2^{\circ}$ to $26.7^{\circ}$ $\left(23^{\circ}\right.$ at the middle swath IS2), and a $5 \times 25 \mathrm{~m}$ nominal pixel dimension. Figure 1 shows the location of this track over the study area. The ASAR scenes have perpendicular baselines ranging from -617.8 to $706.2 \mathrm{~m}$ with respect to the central reference image (master) dated 2 June 2008 and Doppler centroid baselines from -33 to $19 \mathrm{~Hz}$ (Figure $3(\mathrm{~A})$ and $(\mathrm{B})$ ).

\section{Multi-temporal interferometry}

SAR interferometry (InSAR) allows the Earth's surface to be scanned regularly with a given (usually fixed) revisit time. DInSAR exploits the radar phase information of one pair of complex SAR images acquired over the same region at different times (hence, repeat pass SAR interferometry) that are used to form an interferometric pair (the interferogram). This repeated acquisition of images over a given area is usually performed with the same sensor or sensors having identical system characteristics. InSAR was described for the first time by
Table I. Envisat ASAR data for Seville area (Track 94 descending, Frame 2858). Parameters are relative to the master acquisition, orbit 32713, acquired on 02/06/2008 10:35:17 AM (UTC)

\begin{tabular}{llllrrr}
\hline No. & Acq. date & Orbit & Sensor & $B_{\perp}(\mathrm{m})$ & $\mathrm{B}_{\text {temp }}($ days $)$ & $\mathrm{f}_{\mathrm{dc}}(\mathrm{Hz})$ \\
\hline 1 & $24 / 02 / 2003$ & 5158 & ASAR & $-512,3$ & -1925 & 283 \\
2 & $15 / 03 / 2004$ & 10669 & ASAR & 675,8 & -1540 & 233 \\
3 & $28 / 06 / 2004$ & 12172 & ASAR & $-617,8$ & -1435 & 230 \\
4 & $11 / 10 / 2004$ & 13675 & ASAR & 328,7 & -1330 & 231 \\
5 & $20 / 12 / 2004$ & 14677 & ASAR & -100 & -1260 & 237 \\
6 & $04 / 04 / 2005$ & 16180 & ASAR & $-478,5$ & -1155 & 241 \\
7 & $09 / 05 / 2005$ & 16681 & ASAR & 627,9 & -1120 & 235 \\
8 & $18 / 07 / 2005$ & 17683 & ASAR & 706,2 & -1050 & 237 \\
9 & $22 / 08 / 2005$ & 18184 & ASAR & 349,8 & -1015 & 246 \\
10 & $31 / 10 / 2005$ & 19186 & ASAR & 499,7 & -945 & 259 \\
11 & $13 / 02 / 2006$ & 20689 & ASAR & $-394,9$ & -840 & 258 \\
12 & $05 / 03 / 2007$ & 26200 & ASAR & 347,1 & -455 & 267 \\
13 & $24 / 03 / 2008$ & 31711 & ASAR & 225,6 & -70 & 257 \\
$\mathbf{1 4}$ & $\mathbf{0 2 / 0 6 / 2 0 0 8}$ & $\mathbf{3 2 7 1 3}$ & ASAR & $\mathbf{0}$ & $\mathbf{0}$ & $\mathbf{2 6 4}$ \\
15 & $18 / 05 / 2009$ & 37723 & ASAR & $-60,7$ & 350 & 261 \\
16 & $27 / 07 / 2009$ & 38725 & ASAR & $-87,7$ & 420 & 268 \\
17 & $31 / 08 / 2009$ & 39226 & ASAR & 242,5 & 455 & 270 \\
18 & $16 / 08 / 2010$ & 44236 & ASAR & $-53,2$ & 805 & 284 \\
19 & $20 / 09 / 2010$ & 44737 & ASAR & 204,3 & 840 & 276 \\
\hline
\end{tabular}

Table II. Short statistics for the processed SAR dataset

\begin{tabular}{|c|c|}
\hline AOI dimension $\left(\mathrm{km}^{2}\right)$. & 297 \\
\hline Sensor & Envisat ASAR \\
\hline Band & $\mathrm{C}$ \\
\hline Wavelength (cm) & $\sim 5.7$ \\
\hline Incident angle $\left({ }^{\circ}\right)$ & 23 \\
\hline Orbital track & Descending \\
\hline Azimuth $x$ slant range resolution $(\mathrm{m})$ & $4 \times 8$ \\
\hline Multilook factor (Az / Rg) & 11 \\
\hline Georeference accuracy (m) & 25 \\
\hline \multicolumn{2}{|l|}{ Minimum temporal span between } \\
\hline two acquisitions (day) & 35 \\
\hline Acquisition period & 24/02/2003-20/09/2010 \\
\hline Number of scenes & 19 \\
\hline Processing method & PSI + SBAS (StaMPS) \\
\hline PS (PS + SDPF) density (PS/ km²) & $\sim 126$ \\
\hline \multicolumn{2}{|l|}{ Mean LOS velocity (mm/yr) $(90 \%$} \\
\hline population) - Figure 7(A) & \pm 1.64 \\
\hline \multicolumn{2}{|l|}{ Mean LOS velocity $(\mathrm{mm} / \mathrm{yr})(95 \%$} \\
\hline population) - Figure $7(\mathrm{~A})$ & \pm 2 \\
\hline $\begin{array}{c}\sigma_{\text {Mean LOS velocity }}(\mathrm{mm} / \mathrm{yr})(90 \% \\
\text { population })- \text { Figure } 7(\mathrm{~B})\end{array}$ & \pm 1.05 \\
\hline $\begin{array}{c}\sigma_{\text {Mean LOS velocity }}(\mathrm{mm} / \mathrm{yr})(99.5 \% \\
\text { population) - Figure } 7(\mathrm{~B})\end{array}$ & \pm 1.5 \\
\hline
\end{tabular}

Gabriel et al. (1989), using Seasat satellite data. For a general review of SAR interferometry, the reader is referred to Bamler and Hartl (1998) and Rosen et al. (2000), among others.

InSAR is commonly affected by a series of limitations that should be taken into account. First of all, interferograms are affected by temporal and/or geometrical decorrelation (Hanssen, 2001). Second, the interferometric phase is wrapped, and it may be quite difficult (many times impossible) to unwrap it correctly using a single interferogram (Ghiglia and Pritt, 1998). Finally, even if all previous problems are solved, atmospheric artefacts can still ruin the signal of interest, i.e. ground motion. Multi-Temporal Interferometry (MT-InSAR) techniques were developed to overcome the above mentioned limitations.

MT-InSAR techniques allow one to measure and monitor displacements of the Earth's surface over time by employing time series analysis. More generically, MT-InSAR approaches 

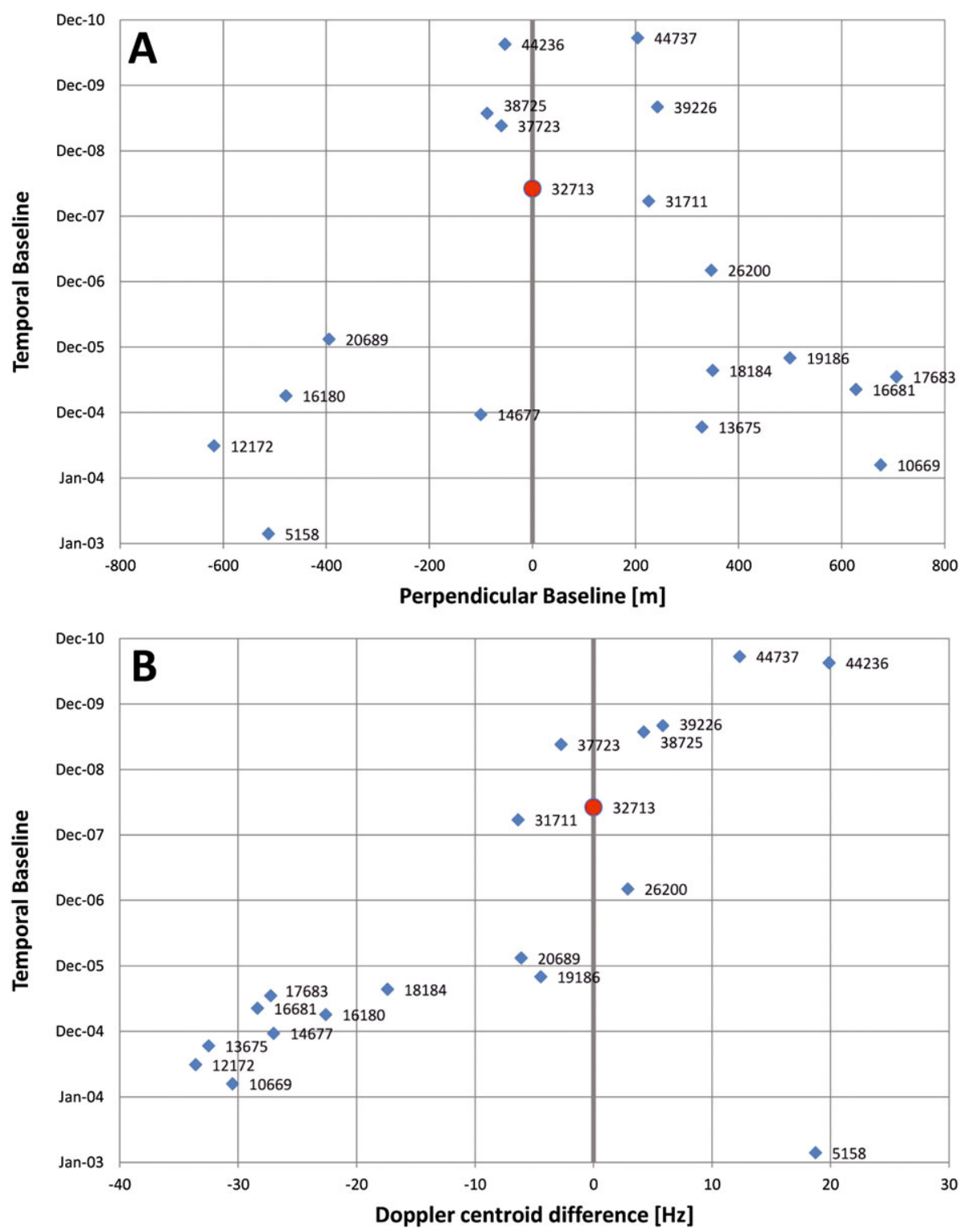

Figure 3. (A) Temporal vs perpendicular baseline distribution and (B) temporal vs Doppler baseline distribution for the SAR dataset used in this study. [Colour figure can be viewed at wileyonlinelibrary.com]

exploit multiple SAR images acquired over the same area, and use appropriate data processing and analysis procedures to separate phase displacement contributions from the other phase components (topography, atmosphere, etc.). These techniques focus on the identification of pixels in the SAR image characterized by small phase noise, typically related to two types of reflectors: those where the response to the radar is dominated by a strong reflecting object and remains constant over time (persistent scatterer or PS), and those where the response is coherent over time, but is due to different small scattering objects (slowly decorrelating filtered phase (SDPF).

For this contribution we employed the software StaMPS, (Hooper et al., 2007; Hooper, 2008). One of the main characteristics of StaMPS is the fact that the persistent scatterer (PS) selection uses phase characteristics, a suitable way to find low-amplitude natural targets with phase stability that cannot be identified by amplitude-based algorithms. In other words, StaMPS uses phase spatial correlation to identify PS pixels instead of amplitude analysis, as in Ferretti et al. (2001), Colesanti and Wasowski (2006), Kampes (2006) and Ketelaar and Gini (2009). Another important advantage is that it does not require a prior deformation model for phase unwrapping.
Furthermore, StaMPS has evolved to a hybrid method based on the extraction of information from both PS and SDFP pixels. It provides the deformation time series; the deformation velocities and the residual topographic error, which represents the difference between the true height of the scattering phase center of a given point and the height of the DEM at this point. This is a key parameter in order to achieve accurate geocoding. Single master interferograms are used for PS pixel selection, while multiple master interferograms with small baselines (SB) are used for SDFP pixel selection. Figure 4 shows the temporal vs spatial baseline distribution for the interferometric dataset used in this study, for both PS and SB processing. The maximum temporal and perpendicular baselines for the PS processing were 1925 days and $706 \mathrm{~m}$, respectively. The interferograms for the small baseline processing (39 in total) were selected with the following criteria: maximum coherence $=0.5$, maximum temporal baseline $=1500$ days, and maximum perpendicular baseline $=1070 \mathrm{~m}$.

StaMPS pixel selection is based on the converged probability distribution, computed as presented in Hooper et al. (2007). The selection strategy consists of finding the selection threshold of the probability distribution for each PS candidate. If the converged probability distribution is greater than the selection 


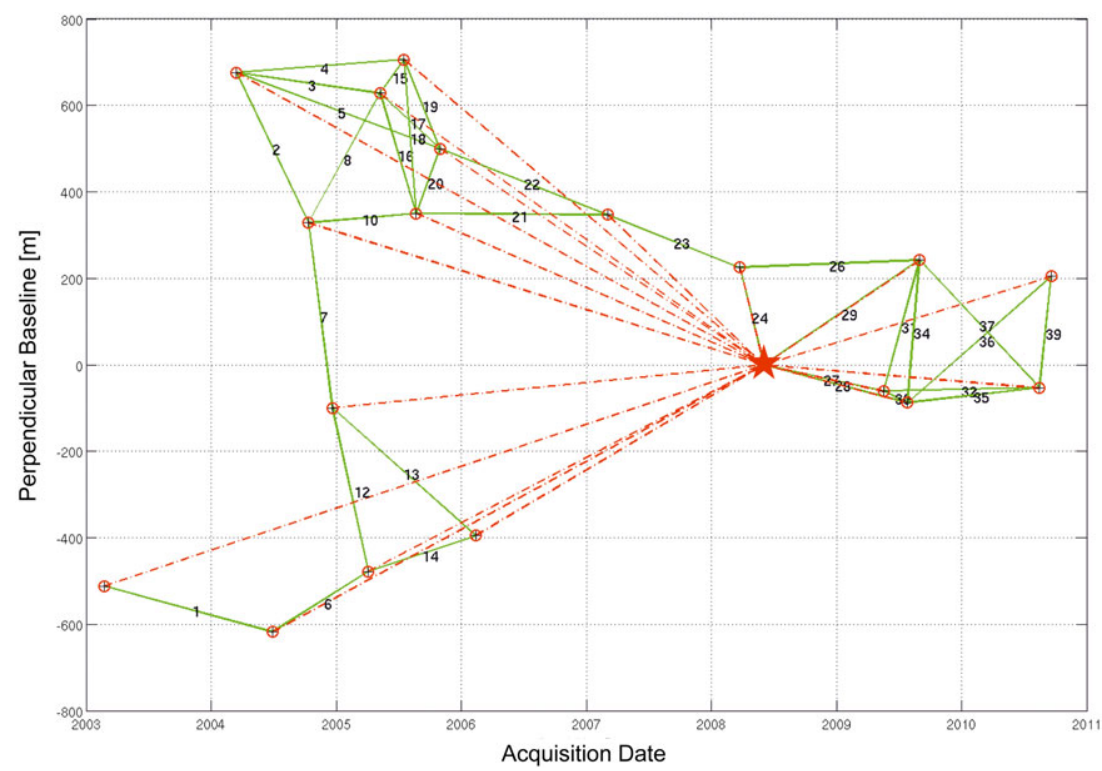

Figure 4. Temporal vs spatial baseline distribution for the SAR dataset used in this study. The dash-dotted red lines represent the single master interferograms used for PS processing while continuous green lines represent the small baseline ones. Master image (02/06/2008, acquisition number 14 , Table I) is symbolized as a red start. [Colour figure can be viewed at wileyonlinelibrary.com]

threshold, the candidate will be initially selected as a coherent pixel, and otherwise it will be discarded. For the initial topographic estimation, and later on for terrain geocoding, we used heights from a DEM provided by the Instituto Geográfico Nacional de España with $25 \mathrm{~m}$ resolution.

After this step, the phases of the selected pixels are unwrapped, which means unfolding the phase outside its natural interval of $[-\pi, \pi]$. Unwrapping errors are corrected on the spatial domain using a minimum cost-flow algorithm for sparse data. However, in StaMPS, the low-spatially correlated part in wrapped interferograms is corrected before unwrapping, including the spatially uncorrelated part of the look angle error and the contribution of the master to the spatially uncorrelated part of the signal. Then, the corrected phases are filtered to reduce phase noise before the final unwrapping process using the filtering method of Goldstein and Werner (1998). After filtering, the selected pixels are used to form a Delaunay network and their triangular elements are used to find the nearest pixel of each grid. The nearest PS/SDFP pixels of all grids are used to form an unwrapping network. The final unwrapping is performed through integration. Other methods for phase unwrapping are presented in Ferretti et al. (2001), Kampes (2006) and Caro Cuenca et al. (2011).

Finally, the unwrapped phases of a single pixel are used to estimate a linear relationship with its spatial perpendicular baselines using the least square method. After estimating look angle error and master atmosphere, the slaves atmosphere is estimated by triangulation. The inner workings of this software package are described in more detail in Hooper (2006, 2008, and 2010), Hooper et al. (2004, 2007) and Sousa et al. (2010, 2011).

\section{SAR results}

We produced ground motion time series for the area of Seville spanning a total of 8 years (February 2003-September 2010). Figure 5 illustrates the spatio-temporal evolution of the accumulated LOS surface displacement for the whole analyzed period referred to the first data. Table II summarizes the main statistics of the processed SAR dataset. A total of 37470 PS
$(\mathrm{PS}+\mathrm{SDFP})$ pixels, highly concentrated in the urban areas, were selected in the study area shown in Figure 6, resulting in an average density of $\sim 126 \mathrm{PS} / \mathrm{km}^{2}$. Figure 6 shows the mean LOS velocity pattern together with its standard deviation. The reference area (assumed to be stable) for phase unwrapping is depicted by a triangle on the bottom left part of the study area in both figures. The PS (PS + SDFP) distributions for the mean LOS velocity and its standard deviation are shown in Figure 7. The mean LOS velocities for most of our PS population lie inside $\pm 1.5-2 \mathrm{~mm} / \mathrm{yr}$ interval with a mean value of $-0.54 \mathrm{~mm} / \mathrm{yr}$, and inside $\pm 1-1.5 \mathrm{~mm} / \mathrm{yr}$ interval in the case of the mean LOS velocity standard deviations (Table II, Figure 7). The standard deviation of the mean LOS velocity is estimated per PS point applying a Montecarlo approach to each time series. A common value considered in literature as the stability threshold, that is, the tolerance that classifies a PS as unstable for this type of C-band radar data is around $\pm 1.5-2 \mathrm{~mm} / \mathrm{yr}$ (Meisina et al., 2008; Cigna et al., 2014; Del Ventisette et al., 2014; Notti et al., 2014; Ciampalini et al., 2015; Frangioni et al., 2015; Novellino, 2015) even $\pm 1 \mathrm{~mm} / \mathrm{yr}$ (Boni et al., 2015). In our case, we also assume this stability threshold on the basis of our statistical analysis. Therefore, a PS with a mean LOS velocity outside $\pm 1.5-2 \mathrm{~mm} / \mathrm{yr}$ interval is considered unstable.

The spatial analysis of subsidence distribution shows that the areas subsiding the most are concentrated along the boundary between the alluvial sediments and the Aljarafe Realm, near the cities of Gelves, Tomares and Camas (Figures 5 and 6). A high concentration of pixels showing medium subsidence values is located by the historical city center, with values around $-3 \mathrm{~mm} / \mathrm{yr}$. On the other hand, the most stable areas are restricted to the Aljarafe Realm and to the alluvial floodplain east of the Guadalquivir main channel. In addition, a grouping of medium subsidence values shows a NE-SW trend and subdivides the stable areas previously described between the river and the Alcores Realm.

Figure 8 shows the displacement time series for the areas with high subsidence rates and other points randomly distributed in the area of interest (see Figures 2 and 12 for location). They represent the average deformation of an area within a radius of $50 \mathrm{~m}$. The maximum subsidence for the period is around $40 \mathrm{~mm}$ (points 9, 12 and 22; Figures 8, 9(B) 

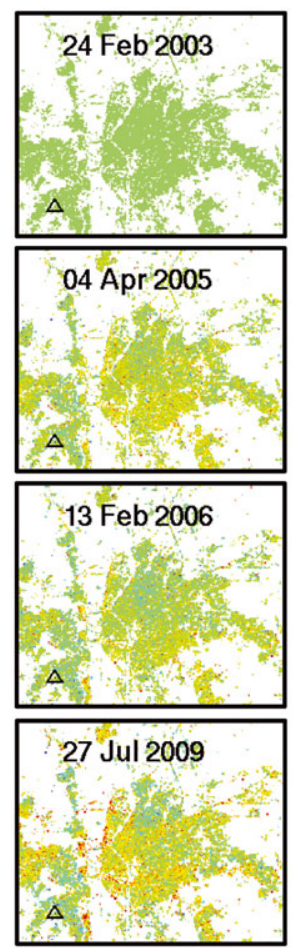
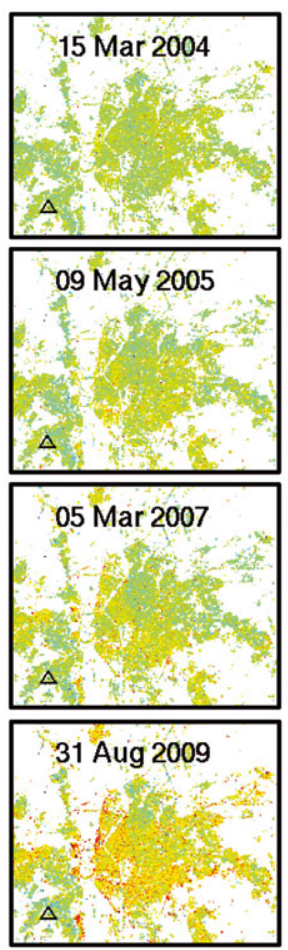
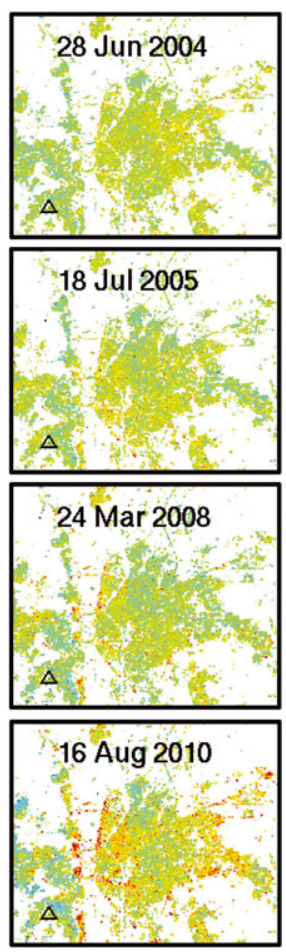
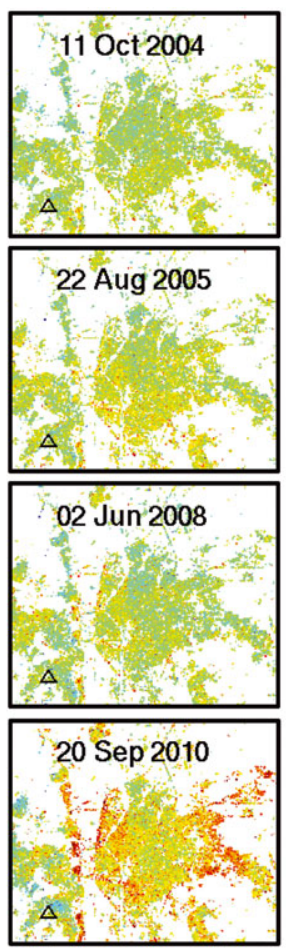
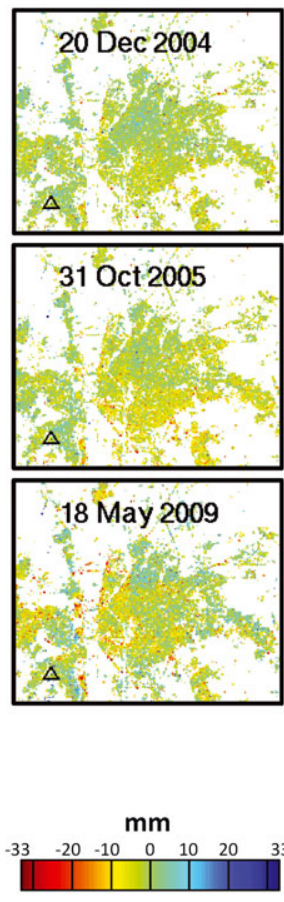

Figure 5. Spatio-temporal evolution of the accumulated LOS displacement for the combined (PS + SB) processing referred to the first data. All the single master interferograms are ordered by date from left to right and top to bottom. The black triangles indicate the reference area assumed to be stable. [Colour figure can be viewed at wileyonlinelibrary.com]

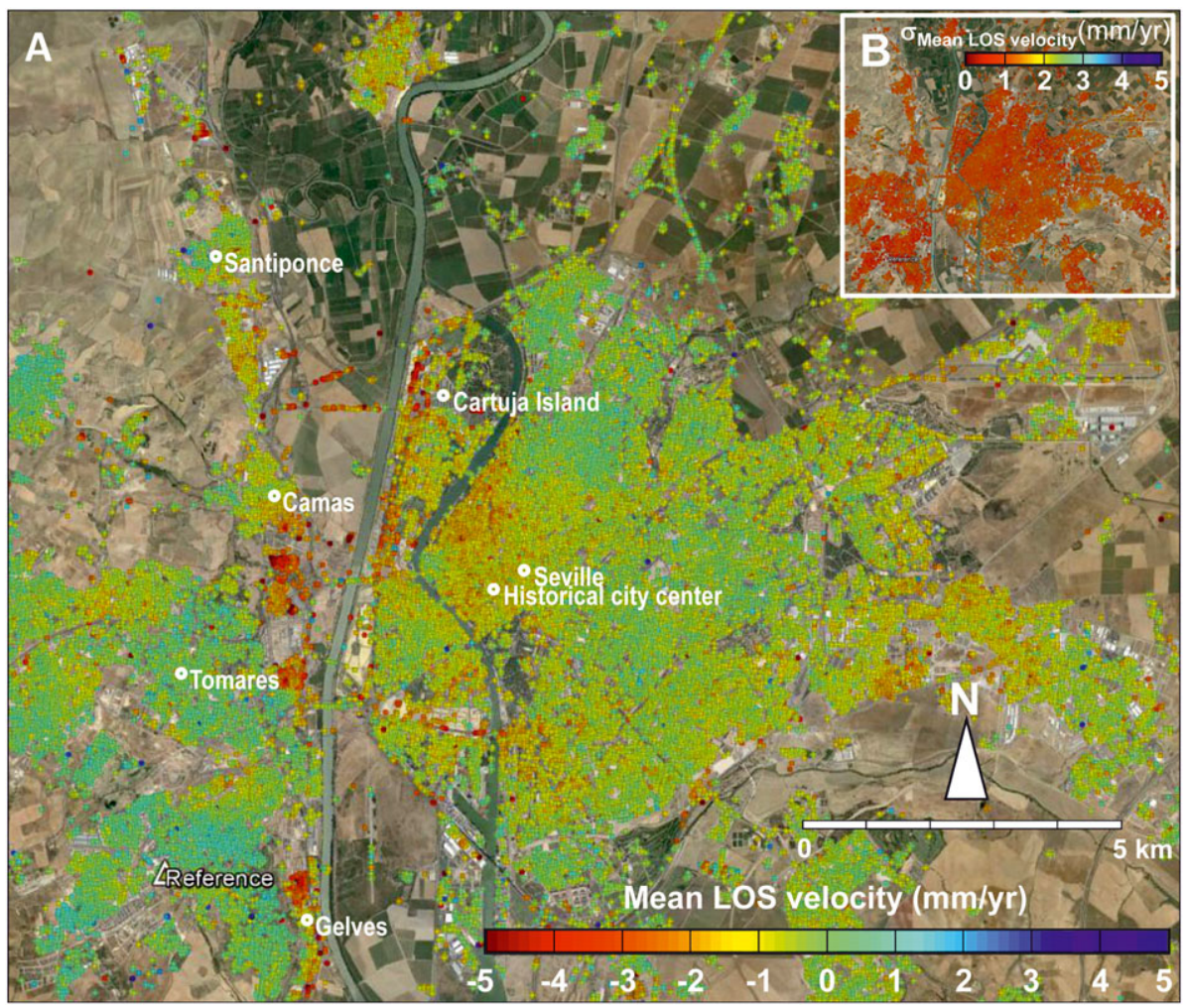

Figure 6. (A) Mean SAR line-of-sight (LOS) velocity, assuming a linear deformation rate, superimposed over a Google Earth image. The white triangle indicates the reference area for phase unwrapping. (B) Standard deviation for mean LOS velocity. [Colour figure can be viewed at wileyonlinelibrary.com]

and 12), at a rate of $-5 \mathrm{~mm} / \mathrm{yr}$. Several periods are seen to have a displacement increase (2004, 2009 and 2010) with rates in the order of $-30 \mathrm{~mm} / \mathrm{yr}$ (Figure 8 ). Other periods, for instance between 2006 and 2009, show a slight subsidence pattern with a gentler slope. There is one year gap in the SAR data from August 2009 to August 2010, so there is no deformation history during this period. However, the subsidence pattern shown in the last two dates (from 16 August 2010 to 20 September 2010, Figures 5 and 8) is correlated with the decrease in the rainfall accumulated deviation (Figure 9(A)), that is, with the drought period in 2010 (shaded area for this year in Figure 9(A)). 

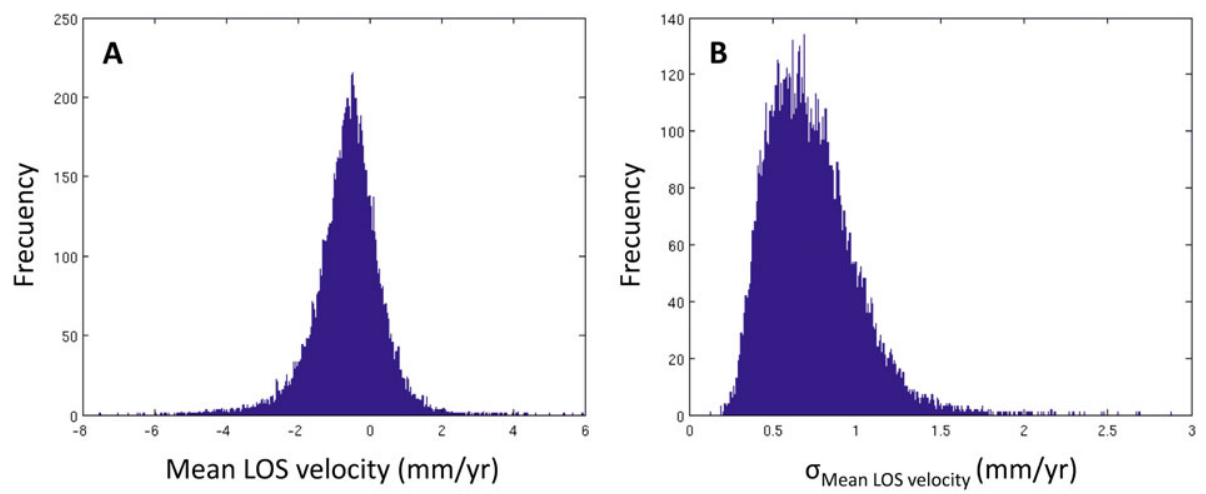

Figure 7. PS distribution for mean LOS velocity (A) and its standard deviation (B) in the study area of Figure 6. [Colour figure can be viewed at wileyonlinelibrary.com]

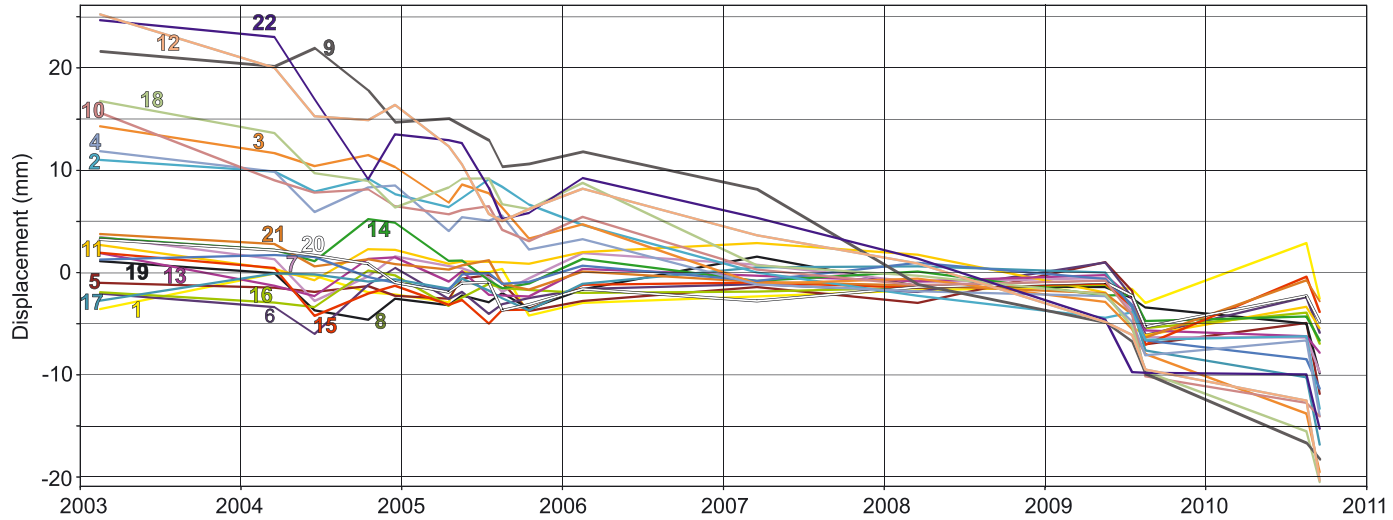

Figure 8. Displacement time series resolved by ASAR descending observations for PS points located in Figures 2 and 12. [Colour figure can be viewed at wileyonlinelibrary.com]

\section{Meteorological data and water table evolution}

River water level and rainfall data series, from the Confederación Hidrográfica del Guadalquivir (CHG) regional network (CHG, 2017), were compiled for the period 2003 to 2010 (Figure 9(A) and (B)). The station is located at the active channel of the Guadalquivir River, where it passes to the east of the city center (Figure 2). The average precipitation for the

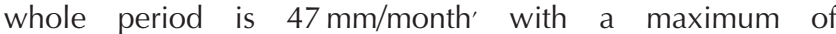
$343 \mathrm{~mm} / \mathrm{month}$ in December 2009. In order to determine the relative deficit or surplus of precipitation in the study area, we calculated the accumulated deviation of monthly precipitation (blue line; Figure 9(A)). This parameter is calculated through the determination of the average monthly precipitation for a long-term period (this study, 2003-2010) and the value obtained is then successively subtracted from the rainfall value for each month. A major drought period could be easily distinguished along the trend of the rainfall accumulated deviation between the years 2004 and 2006. In addition, several minor episodes of low rainfall rate can be distinguished in 2003, 2009 and 2010.

Correlation of deformation data with the water table evolution in the different subsiding sectors was not possible due to the scarcity and irregularity of the piezometric measurements in this area. As representative of the aquifer, we give the water level record of a piezometer managed by the $\mathrm{CHG}(\mathrm{CHG}, 2017)$ slightly east of the study area (black line; Figure 9(A)), at the village of Alcalá de Guadaira (Figure 2). In areas far away from the river channel, the piezometric trend is seen to reflect a similar pattern to the rainfall accumulated deviation but with a temporal delay. In turn, in the surroundings of the river the subsurface water content is highly conditioned by the oscillations in its water column, conditioned by the anthropic regulation of its flow rate. This level is fairly stable over time (Figure 9), especially in the drought periods, with values around 0.4-0.7 m.a.s.l. However, punctual rises are observed to the end of the analyzed time span, reaching values of up to 2.7 m.a.s.l.

In Figure 10, we have analyzed the coefficient of determination ( $\mathrm{R}^{2}$; square of the Pearson correlation coefficient) between the river evolution, the rainfall, the piezometric level and the subsiding trend of several points randomly distributed along the whole area in a 6 year period (2003-2008). This time span was selected avoiding the water river peak observed in the final part of the InSAR studied period (2009-2010) as it distorts the general pattern and because of the scarcity of SAR data. This coefficient quantifies the proportion of the subsidence that is explained by these variables. It varies between 0 (without correlation) and 1 (total correlation) but could also be expressed as a percentage (Figure 10). Points analyzed have been divided into three different groups with respect to the results of the correlation analysis. Subsidence of points located at the right margin of the Guadalquivir historic channel $(2,3,4,9,10,12$ and 18; Group 1) is mainly explained by the river level evolution $\left(50<\mathrm{R}^{2}<90 \%\right)$. In addition, their subsidence trend is well correlated $\left(R^{2}>75 \%\right)$ with those points of the same group. Points in Group $3(1,5,6,7,8,11,13,15,16$ and 17) are located at stable areas with no river influence $\left(R^{2}<10 \%\right)$ and whose subsidence trend has no correlation with points of the same or other groups $\left(R^{2}<25 \%\right)$. Group 2 (points 14,19 , 20, 21 and 22) represents intermediate situations of areas located at the left margin of the historic channel or at tributary channels $\left(30<\mathrm{R}^{2}<70 \%\right)$. The unique exception is point 22 , included in Group 2, but located at the right margin of the river. 

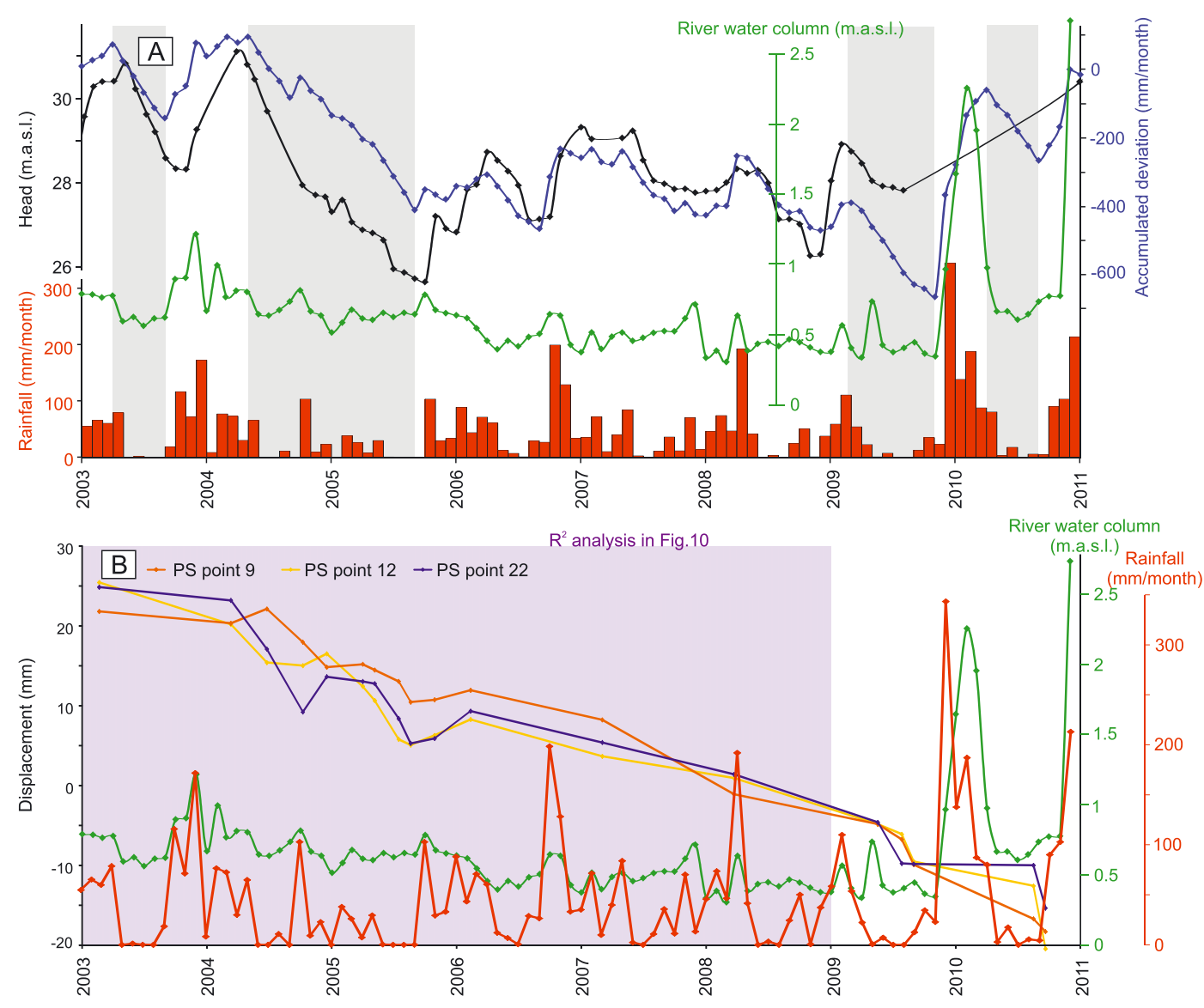

Figure 9. (A) Rainfall (red bars) and piezometric level evolution (black line) together with accumulated deviation of monthly precipitation (blue line) and river water column (green line), for the period 2003 to 2010. Location of the piezometer is marked in Figure 2 at right bottom. Drought periods correspond to gray-shaded areas; and (B) comparison of points 9, 12 and 22 time series with river water column (green line) and rainfall (red line) for the period 2003 to 2010. Purple-shaded area corresponds to the period analyzed in Figure 10. The deformation history is in the LOS direction. [Colour figure can be viewed at wileyonlinelibrary.com]

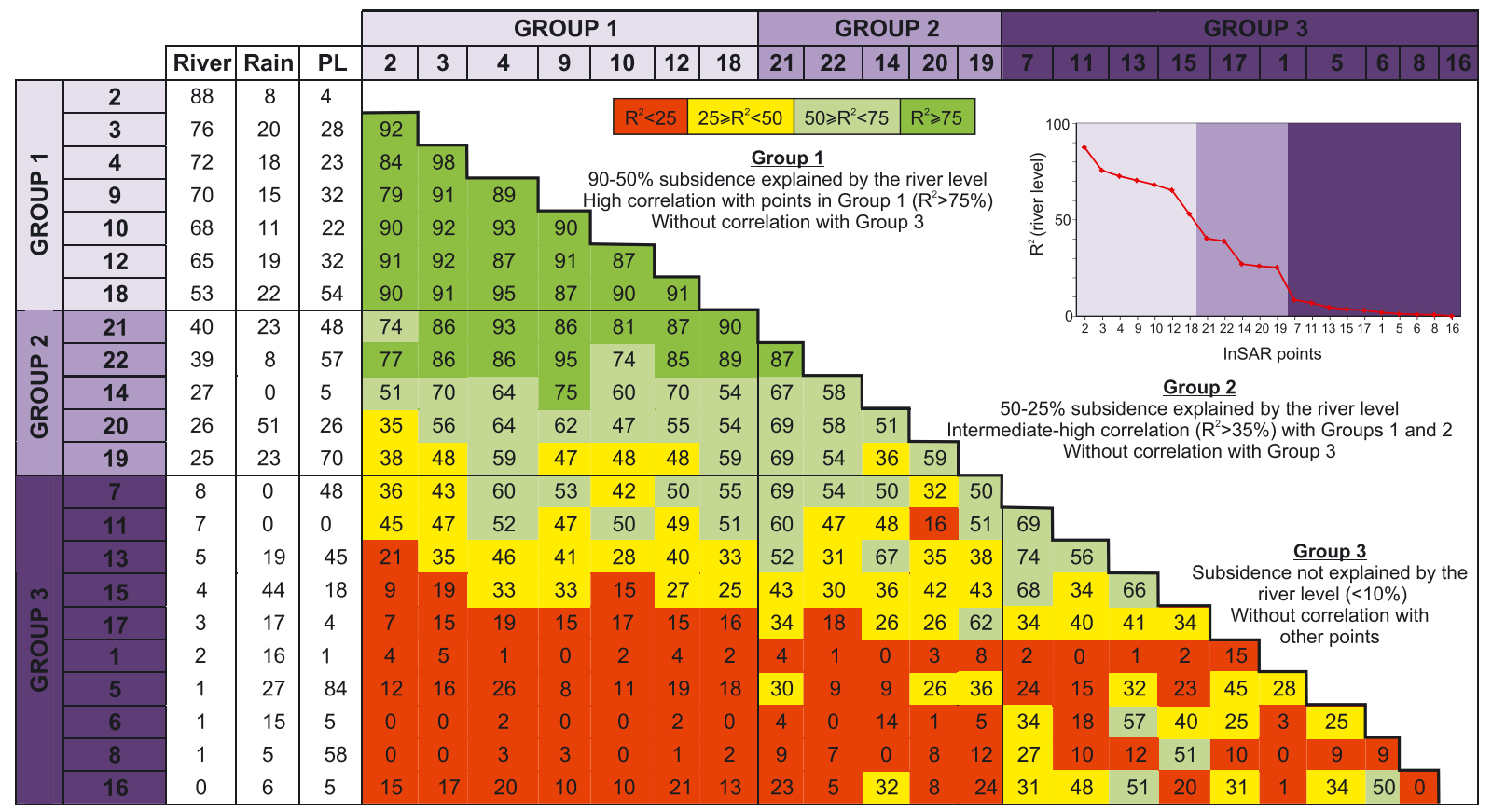

Figure 10. Coefficient of determination $\mathrm{R}^{2}$ (expressed as a percentage) showing correlation between river water level, rainfall, piezometric level and subsidence at PS points located in Figures 2 and 12. [Colour figure can be viewed at wileyonlinelibrary.com]

\section{Geotechnical data}

36 boreholes from different geotechnical studies (IGME, 1990) were analyzed in order to compare three sectors along a W-E transect of the city center: the western margin of the river channel (zone A; most subsiding sector, as detected by means of the InSAR technique): the eastern margin in a position close to the river channel (zone B); and the eastern margin at a 


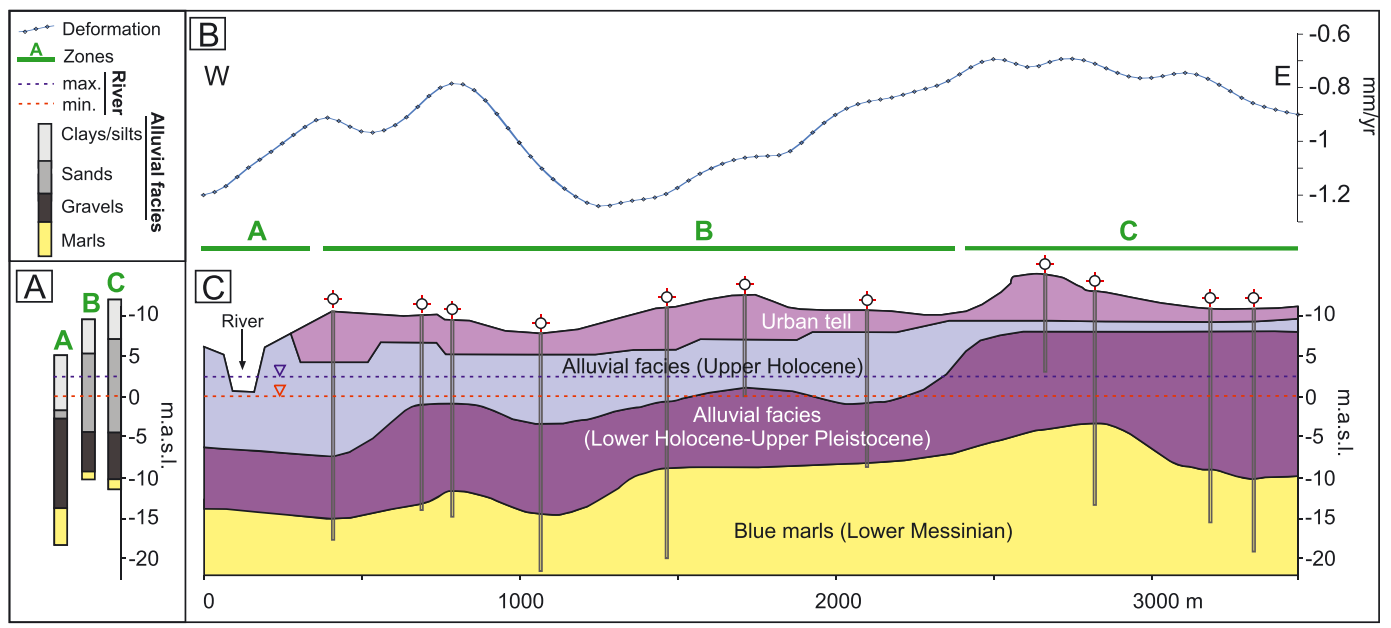

Figure 11. (A) Lithological column type for A, B and C zones; (B) deformation profile along the W-E transect of the Seville city-center indicated in Figures 2 and 12; and (C) geological cross-section modified from Borja and Barral (2003). [Colour figure can be viewed at wileyonlinelibrary.com]

Table III. Geotechnical parameters of the sediments in the study area. $\gamma_{\text {sat }}=$ saturated density $\left(\mathrm{Tn} / \mathrm{m}^{3}\right) ; \gamma_{\mathrm{h}}=$ natural density $\left(\mathrm{Tn} / \mathrm{m}^{3}\right) ; \mathrm{c}=$ effective cohesion (KPa); $\phi=$ effective internal friction angle (deg)

\begin{tabular}{|c|c|c|c|c|c|}
\hline Sector. & Silts and clays & Sands & Gravels & Blue marls & Settlement $(\mathrm{mm})$ \\
\hline A & $\begin{array}{l}\gamma_{\mathrm{h}}=17 \mathrm{kN} / \mathrm{m}^{3} \\
\gamma_{\mathrm{sat}}=21 \mathrm{kN} / \mathrm{m}^{3} \\
\mathrm{c}^{\prime}=5 \mathrm{kPa} \\
\phi^{\prime}=23^{\circ}\end{array}$ & $\begin{array}{l}\gamma_{\mathrm{h}}=20 \mathrm{kN} / \mathrm{m}^{3} \\
\gamma_{\mathrm{sat}}=23 \mathrm{kN} / \mathrm{m}^{3} \\
\mathrm{c}^{\prime}=15 \mathrm{kPa} \\
\phi^{\prime}=28^{\circ}\end{array}$ & $\begin{array}{l}\gamma_{\mathrm{h}}=21 \mathrm{kN} / \mathrm{m}^{3} \\
\gamma_{\mathrm{sat}}=21 \mathrm{kN} / \mathrm{m}^{3} \\
\mathrm{c}^{\prime}=0 \mathrm{kPa} \\
\phi^{\prime}=33^{\circ}\end{array}$ & $\begin{array}{l}\gamma_{\mathrm{h}}=19 \mathrm{kN} / \mathrm{m}^{3} \\
\gamma_{\mathrm{sat}}=21 \mathrm{kN} / \mathrm{m}^{3} \\
\mathrm{c}^{\prime}=100 \mathrm{kPa} \\
\phi^{\prime}=20^{\circ}\end{array}$ & 7.70 \\
\hline B & $\begin{array}{l}\gamma_{\mathrm{h}}=16 \mathrm{kN} / \mathrm{m}^{3} \\
\gamma_{\mathrm{sat}}=19 \mathrm{kN} / \mathrm{m}^{3} \\
\mathrm{c}^{\prime}=70 \mathrm{kPa} \\
\phi^{\prime}=20^{\circ}\end{array}$ & $\begin{array}{l}\gamma_{\mathrm{h}}=20 \mathrm{kN} / \mathrm{m}^{3} \\
\gamma_{\mathrm{sat}}=21 \mathrm{kN} / \mathrm{m}^{3} \\
\mathrm{c}^{\prime}=5 \mathrm{kPa} \\
\phi^{\prime}=28^{\circ}\end{array}$ & $\begin{array}{l}\gamma_{\mathrm{h}}=21 \mathrm{kN} / \mathrm{m}^{3} \\
\gamma_{\mathrm{sat}}=21 \mathrm{kN} / \mathrm{m}^{3} \\
\mathrm{c}^{\prime}=0 \mathrm{kPa} \\
\phi^{\prime}=33^{\circ}\end{array}$ & $\begin{array}{l}\gamma_{\mathrm{h}}=19 \mathrm{kN} / \mathrm{m}^{3} \\
\gamma_{\mathrm{sat}}=21 \mathrm{kN} / \mathrm{m}^{3} \\
\mathrm{c}^{\prime}=100 \mathrm{kPa} \\
\phi^{\prime}=20^{\circ}\end{array}$ & 2.52 \\
\hline C & $\begin{array}{l}\gamma_{\mathrm{h}}=17 \mathrm{kN} / \mathrm{m}^{3} \\
\gamma_{\mathrm{sat}}=20 \mathrm{kN} / \mathrm{m}^{3} \\
\mathrm{c}^{\prime}=70 \mathrm{kPa} \\
\phi^{\prime}=20^{\circ}\end{array}$ & $\begin{array}{l}\gamma_{\mathrm{h}}=20 \mathrm{kN} / \mathrm{m}^{3} \\
\gamma_{\mathrm{sat}}=21 \mathrm{kN} / \mathrm{m}^{3} \\
\mathrm{c}^{\prime}=5 \mathrm{kPa} \\
\phi^{\prime}=28^{\circ}\end{array}$ & $\begin{array}{l}\gamma_{\mathrm{h}}=21 \mathrm{kN} / \mathrm{m}^{3} \\
\gamma_{\mathrm{sat}}=21 \mathrm{kN} / \mathrm{m}^{3} \\
\mathrm{c}^{\prime}=0 \mathrm{kPa} \\
\phi^{\prime}=33^{\circ}\end{array}$ & $\begin{array}{l}\gamma_{\mathrm{h}}=19 \mathrm{kN} / \mathrm{m}^{3} \\
\gamma_{\mathrm{sat}}=21 \mathrm{kN} / \mathrm{m}^{3} \\
\mathrm{c}^{\prime}=100 \mathrm{kPa} \\
\phi^{\prime}=20^{\circ}\end{array}$ & 5.74 \\
\hline
\end{tabular}

position further from the river (zone C; most stable sector). The synthetized lithological column of these sectors (Figure 11(A)) shows an increase of the grain size in depth, with prevalence of silts and clays at the upper part and gravels at the bottom. In all of them, an aquitard blue marls formation is located around 20-22 $\mathrm{m}$ deep from the surface. The columns mainly differ in terms of the thickness of coarse-grained sediments and the features of the fine-grained sediments at the upper part. Whereas in sector $\mathrm{A}$ the thickness of coarse-grained sediments is around $12 \mathrm{~m}$, in zones $\mathrm{B}$ and $\mathrm{C}$ the sandy facies prevail and coarse-grained sediments thickness is in the range $5-7 \mathrm{~m}$. On the other hand, the upper part of the column in sector B is constituted of silty sands with medium plasticity, in contrast to sector A where clayey silts with high plasticity prevail.

Tests were carried out on undisturbed samples of the main lithologies found in the region in order to characterize the geotechnical parameters required to calculate the settlement expected in each of the sectors (Table III). Differences in consistency between silts and clays play an important role in subsidence, as does the calculated effective cohesion, ranging from $5 \mathrm{kPa}$ in zone $\mathrm{A}$ to $70 \mathrm{kPa}$ in zones $\mathrm{B}$ and $\mathrm{C}$. The estimated settlement in the most subsiding sector $A$ shows a value of $7.70 \mathrm{~mm}$. Meanwhile, in zones B and C the average value is 2.52 and $5.74 \mathrm{~mm}$, respectively.

\section{Discussion and conclusion}

In this section, the InSAR data are spatially and temporally compared with several conditioning factors (type, thickness and consolidation degree of the sedimentary facies) and some triggering factors of subsidence (river water column, piezometric level and rainfall evolution).

\section{Conditioning factors of subsidence}

Sedimentary facies distribution related to fluvial dynamics The ground motion estimated with InSAR reveals land deformation in Seville during the period comprised between February 2003 and September 2010. The main feature is the close spatial relationship between the under-consolidated fluvial sediment distribution and the subsidence. Regions where subsidence shows higher values (Figures 8 and 12) are related to the main channel of the river, and to the distribution of historical branches of the Guadalquivir River and its tributaries as well as the abandoned meanders.

The displacement maps indicate several subsidence maxima near the villages of Gelves, Tomares, and Camas $(-40 \mathrm{~mm})$ and Santiponce $(-25 \mathrm{~mm})$, respectively, points $22,18,12,9$, and 2 


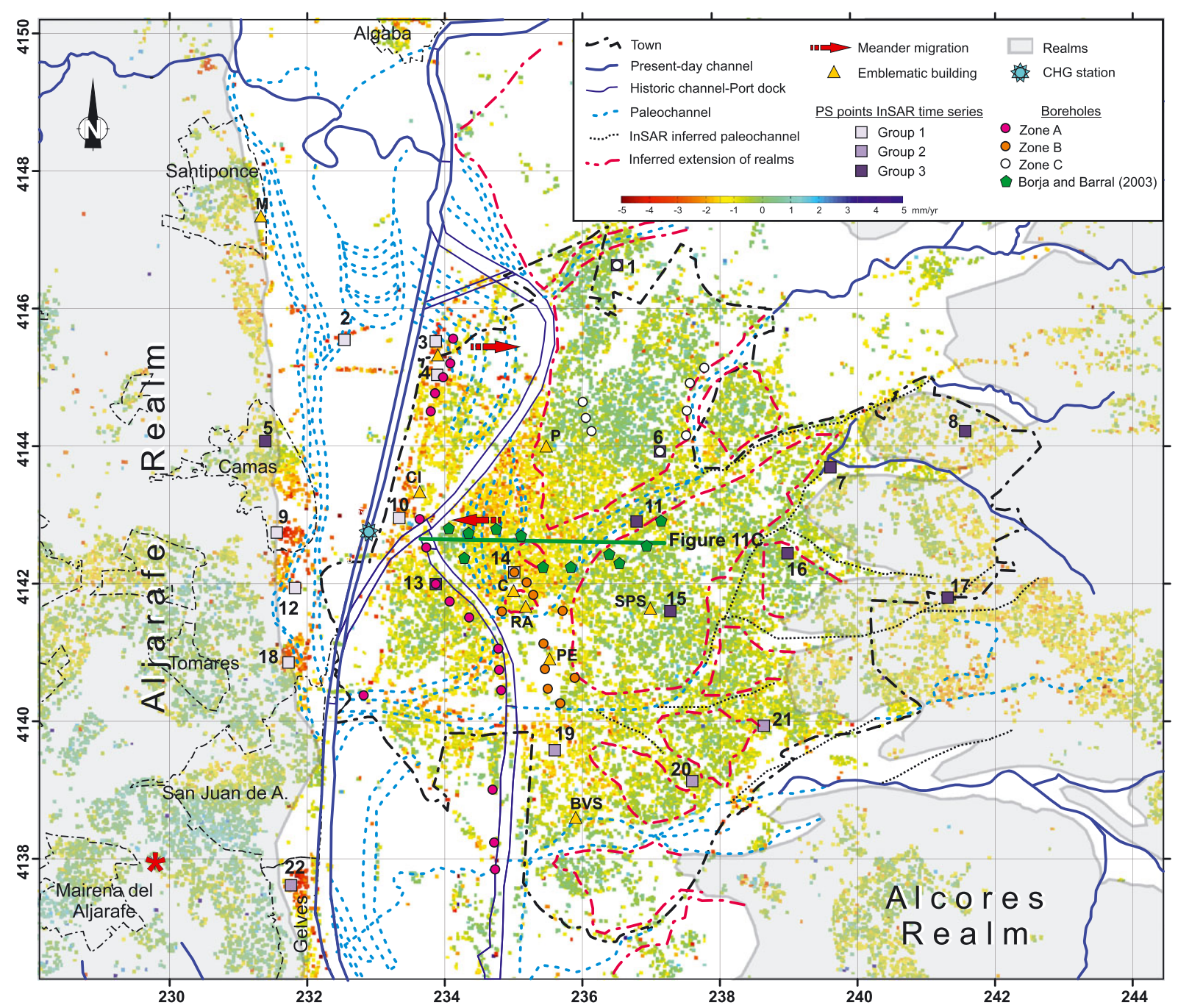

Figure 12. Channel and paleochannel distribution superimposed over the geocoded radar mean LOS velocity, assuming a linear deformation rate. Color scale as Figure 6(A). [Colour figure can be viewed at wileyonlinelibrary.com]

(Figures 8 and 12), along the western margin of the Guadalquivir River floodplain. This subsiding ribbon attached to the Aljarafe realm correlates spatially with the location of the so-called 'Madre Vieja', an ancient paleochannel that flowed through the western side of the alluvial plain at preRoman times (del Moral Ituarte, 1991; Borja and Barral, 2005). Afterwards, this channel functioned sporadically during the main flooding events. Other important subsiding sectors are located along the part of the city attached to the historic channel and its meanders (points 2, 3, 4, 10 and 14, Figures 8 and 12). This area is made up of sediments that reach a thickness of over $20 \mathrm{~m}$, with prevalence of fine-grained facies. Geotechnical results forecast the high subsidence values detected through the InSAR technique at this area, where the upper clayey silts (with cohesion of $5 \mathrm{kPa}$ ) are around $7 \mathrm{~m}$ thick. Structural damages in buildings or sidewalks of the most subsiding areas have not been reported; probably because they are wide enough to absorb uniformly the deformation and to avoid differential settlements in individual buildings.

To the east, areas with a linear pattern of subsidence may represent other paleochannels coming from the Alcores calcarenitic realms to the Guadalquivir River (Figure 12). Some have been described in previous works (dashed blue lines), such as the eastward position of the river in Roman times (around point 14). Others seem to correspond to old tributaries (dashed black lines), but could not be confirmed since they have not been documented until now. This subsidence pattern supports the hypothesis of a fluvial model with multiple wide and shallow channels that may evolve to a deeper winding one (Díaz del Olmo and Borja, 1991; García et al., 1999). The last stage of the transformation of the Guadalquivir network from the braided system to the meander system occurred around $1000 \mathrm{BP}$. In between these paleochannels could be observed the existence of most stable areas related with the outcrops of the Aljarafe (point 5) and the Alcores Realm (points 1,8 and 17) or some terrace levels (dashed red lines) sealed by the present-day floodplain sediments (points 6, 15 and 16). The extent of these consolidated levels has been inferred from geomorphological data, analysis of correlation coefficients and previous studies (Barral, 2004, 2009).

The episodic character of the fluvial sedimentary system produces a record characterized by high lateral and vertical facies variability (Miall, 1977; Wright and Marriott, 1993). In transition with point bar sediments due to the progradation of the river, coarse-grained deposits can be observed related to sudden ruptures of the channel (chute bars) or overflowings (crevasse splay) and fine-grained sediments typical of the floodplain or impoundment areas. In the area of Seville, this high variability has been synthetized in the surroundings of the Guadalquivir River in several lithological columns that allow the definition of three different zones in a W-E crosssection through the city center (Figure 11), orthogonal to the Guadalquivir River channel at Roman times. Although in all cases the grain size increases with depth, the greater thickness 
of fine-grain sediments is found at the western margin of the river (Zone A). Zones B and C, at the eastern margin, show a similar proportion of fine grain sediments and differences are related to the amount of sands and gravels. Settlement values (Table III) confirm that greater values of subsidence will be located at zone A $(7.70 \mathrm{~mm} / \mathrm{yr})$, mainly due to fine-grain sediment compaction (Poland, 1984; Galloway et al., 1999). However, theoretical settlement in zones B and C (2.52 and $5.74 \mathrm{~mm} / \mathrm{yr}$, respectively) differs from the observed subsidence detected with InSAR data. This difference is probably related, as we will discuss below, to the consolidation degree of sediments and their topographical position with respect to water level fluctuation.

\section{Consolidation degree and anthropic infill}

We compare the synthetized borehole lithological columns (Figure 11(A)) with an east-west section across the city-center (Figure 11(B)), performed by Borja and Barral (2003). This section is not focused on lithology but on the degree of consolidation of the alluvial facies due to the river activity during Quaternary times. Authors point out that the top of the sedimentary sequence, mainly constituted of silts and clays, appears frequently interlayered with variable anthropic deposits of different historical epochs, the so called 'urban tell' (Barral et al., 2007). Urbanization in the Guadalquivir alluvial valley dates back more than 2500 years and historic buildings of different periods (Roman, Visigothic, Muslim...) still remain nowadays, meanwhile others have been successively reconstructed over the foundations of previous ones. This long-lasting history is revealed by diverse man-made fills (urban tell) highly variable in thickness that in some sites reach up to $7 \mathrm{~m}$ but in others are practically absent (Barral et al., 2007). It should be borne in mind that this anthropic infill may partially contribute to the total subsidence detected in the fine-grain sedimentary record. However, a rigorous correlation of the expected subsidence due to these urbanization variables would suffer a too large a number of uncertainties as detailed mappings of the man-made fill thickness and nature are not available.

Below the urban tell (Figure 11(C)), alluvial deposits (10-17 m), assigned to different terrace levels (Baena Escudero, 1993) are mainly composed of sands, with increasing amount of gravels towards the base. Consolidated sediments that constitute the older terraces are shallower at zone $C$ corresponding with the most stable areas (points 1, 6, 15 and 16 in Figure 12), as could also be observed in the deformation profile obtained for this section (Figure 11(B)). The increase in the thickness of underconsolidated facies is revealed by higher subsidence rates in Zone B (points 11, 14, 19 and 20). This feature is amplified at the river channel and its western margin (Zone A; e.g. points 3, 4 and 10) by the joint action of the increasing fine-grain sediments proportion in the range of water level fluctuations.

\section{Triggering factors of subsidence}

The compressibility of the pore structure of a sedimentary aquifer system is mainly supported by the combination of the granular skeleton and the fluid pressure of the groundwater filling the intergranular spaces (Meinzer, 1928). Moreover, aquifers primarily constituted of fine-grained sediments, silts and clays, are much more compressible than those mostly formed by coarse-grained sediments (sand and gravel). Deformation time series of points distributed throughout the study area (Figure 8) has been correlated with the river water column, the rainfall and the piezometric level (Figures 9 and 10). Subsidence episodes are well correlated with drought periods in 2004,
2005, 2009 and 2010, with a slight temporal lag (Figure 9). However, the availability of the analyzed InSAR images does not allow us to extend this correlation to the drought of 2003.

Results point to an important relationship between the subsidence trend and the evolution of the river water column for areas to the west of the river channel (Group 1), with more than $50 \%$ of the subsidence justified by river dynamics. In addition, subsidence evolution of points included in this group is coherent among them, with only a minor proportion of the vertical displacement justified by local factors such as the anthropic infill. In contrast, points included in group 3 are not affected by the river evolution (less than $10 \%$ of the subsidence is justified) and their subsidence trend is independent of other points. Points of Group 2 are generally located at the tributary channels and show intermediate situations (25-50\% of subsidence related to the river). The piezometric level measured in the Alcores Realm roughly shows the same pattern, but the influence of the river evolution is particularly evident. On the other hand, rainfall correlation is low in all the points (less than 50\%), wherever they are located. This situation may be the result of two causes: the upstream anthropic regulation of the Guadalquivir flow rate in order to avoid floods and the absence of direct infiltration due to the low permeability of urbanized areas where runoff waters are evacuated by the sewer service. Finally, the maximum and minimum Guadalquivir water level for the studied period (0.302.73 m.a.s.l.) are superimposed on the lithological columns and the cross-section (Figures 11(A) and 11(C)) confirming that greater subsidence values are localized at areas where under-consolidated fine-grained sediments are at the water level range of variation.

\section{Conclusions}

We have analyzed subsidence in the city of Seville (southern Spain) through the results obtained with the Multi-Temporal InSAR (MT-InSAR) technique, during the period 2003 to 2010. Spatial extent of subsidence is controlled by the distribution of under-consolidated fine-grained fluvial sediments at heights comprised in the range of river level variation, mostly at the western margin of the river and the surroundings of its tributaries. In addition, temporal correlation between river level evolution and subsidence reveals its importance as triggering factor in this sector. Furthermore, this influence is not observed at the eastern margin due to the shallow presence of consolidated coarsegrained sediments of different terrace levels. The absence of correlation between subsidence and rainfall evolution is probably caused by the anthropic regulation of the river and the absence of direct infiltration in urbanized areas.

The results presented here could prove helpful to implement appropriate urban planning strategies that account for the subsidence tendency of the sectors located above underconsolidated fluvial deposits. In the absence of ground-water pumping in the area, the water level evolution within the alluvial aquifer is directly linked to the subsurface water content, the hydraulic properties of the aquifer and its thickness. In addition, the InSAR technique could be used to characterize the drainage network evolution of rivers interlinked with urbanized areas. This technique is very useful to visualize potential paleochannel morphologies, patterns known to be of high relevance for reconstructing fluvial dynamics.

Acknowledgements -SAR data are provided by the European Space Agency (ESA) in the scope of 9386 CAT-1 project. This research was supported by PRX 12/00297, ESP2006-28463 and CGL2016-80687-R 
(AEI/FEDER, UE) projects and UJA2015/08/05, PAIUJA 2017/2019 and CEACTierra projects from the University of Jaén (Spain). Additional support came from the RNM-148 and the RNM-282 research groups of the Junta de Andalucía (Spain). Interferometric data were processed using the public domain SAR processor DORIS and StaMPS/MTI. The DEM was freely provided by Instituto Geográfico Nacional de España. The satellite orbits used are from Delft University of Technology and ESA.

\section{References}

Amelung F, Galloway DL, Bell JW, Zebker HA, Laczniak RJ. 1999. Sensing the ups and downs of Las Vegas: InSAR reveals structural control of land subsidence and aquifer-system deformation. Geology 27(6): 483-486 https://doi.org/10.1130/0091-7613(1999)027<0483: STUADO $>2.3 . \mathrm{CO} ; 2$.

Baena Escudero R. 1993. Evolución Cuaternaria (3 M.a.) de la Depresión del Medio-Bajo Guadalquivir y sus márgenes (CórdobaSevilla). Geomorfología, Aluvionamientos, Formaciones superficiales y Secuencia Paleolítica. PhD Thesis, Universidad de Sevilla, Spain.

Baena R, Díaz del Olmo F. 1994. Cuaternario aluvial de la depresión del Guadalquivir: episodios geomorfológicos y cronología paleomagnética. Geogaceta 15: 102-104.

Bamler R, Hartl P. 1998. Synthetic aperture radar interferometry. Inverse Problems 14: R1-R54.

Barral MA. 2004. Estudio geoarqueológico de la ciudad de Sevilla. Antropización y reconstrucción paleogeográfica durante el Holoceno reciente (últimos 2.500 años). PhD Thesis, Universidad de Huelva, Spain.

Barral MA. 2009. Estudio geoarqueológico de la ciudad de Sevilla. Antropización y Reconstrucción Paleogeográfica durante el Holoceno Reciente. Universidad de Sevilla and Fundación FocusAbengoa: Sevilla 668 p.

Barral MA, Borja F. 2002. Aproximación a la evolución paleogeográfica histórica del sector sur del casco antiguo de Sevilla. In Aportaciones a la geomorfología de España en el inicio del tercer milenio, Pérez González A, Vegas J, Machado MJ (eds). Instituto Geológico y Minero de España (Madrid); 19-23.

Barral MA, Recio JM, Serrano I, Borja F. 2007. Propuesta de clasificación de facies de tell urbano en el casco histórico de la ciudad de Sevilla (SW España). M.A. Abstracts XII Reunión Nacional de Cuaternario, Ávila.

Becker RH, Sultan M. 2009. Land subsidence in the Nile Delta: inferences from radar interferometry. The Holocene 19(6): 949-954.

Bell JW, Amelung F, Henry CD. 2012. InSAR analysis of the 2008 RenoMogul earthquake swarm: evidence for westward migration of Walker Lane style dextral faulting. Geophysical Research Letters 39(18) L18306. https://doi.org/10.1029/2012GL052795.

Bell JW, Amelung F, Ferretti A, Bianchi M, Novali F. 2008. Permanent scatterer InSAR reveals seasonal and long-term aquifer-system response to groundwater pumping and artificial recharge. Water Resources Research 44(2): W02407 https://doi.org/10.1029/2007WR006152.

Bledsoe BP, Watson CC. 2001. Effects of urbanization on channel stability. Journal of the American Water Resources Association 37: 255-270.

Boni R, Herrera G, Meisina C, Notti D, Béjar-Pizarro M, Zucca F, González PJ, Palano M, Tomás R, Fernández J, Fernández-Merodo JA, Mulas J, Aragón R, Guardiola-Albert C, Mora O. 2015. Twentyyear advanced DInSAR analysis of severe land subsidence: The Alto Guadalentín Basin (Spain) case study. Engineering Geololgy 198: 40-52 https://doi.org/10.1016/j.enggeo.2015.08.014.

Borja Barrera F. 1992. Cuaternario reciente, Holoceno y Periodos Históricos del SW de Andalucía. Paleogeografía de medios litorales y fluvio-litorales en los últimos 30.000 años. PhD thesis, Universidad de Sevilla, Spain.

Borja Barrera F. 1995. El Río de Sevilla. La Ilanura aluvial del Guadalquivir durante los tiempos históricos. In El último siglo de la Sevilla Islámica, 1147-1248, Valor M (ed). Universidad de Sevilla y Gerencia Municipal de Urbanismo: Sevilla; 24-37.

Borja F, Barral MA. 2005. Evolución histórica de la Vega de Sevilla. Estudio de Geoarqueología urbana. In La Catedral en la ciudad (I), Jiménez A (ed). Sevilla, de Astarté a San Isidoro: Sevilla; 5-36.

Borja FB, Barral M. 2003. Urbe y vega de Sevilla. Estudio geoarqueológico. In: Arqueología y Rehabilitación en el Parlamento de Andalucía. Investigaciones Arqueológicas en el Antiguo Hospital de las Cinco Llagas de Sevilla. Vázquez Labourdete (eds). Junta de Andalucía: 103-113.

Borja Palomo F. 1878. Historia crítica de las riadas o grandes avenidas del Guadalquivir en Sevilla desde su reconquista hasta nuestros días. Excmo. Ayto de Sevilla, vol. 1 Colección Clásicos sevillanos, 2001.

Braga G, Gervasoni S. 1989. Evolution of the Po river: an example of the application of historic maps. In Historical Change of Large Alluvial Rivers: Western Europe, Petts GE, Möller H, Roux AL (eds). John Wiley \& Sons: Chichester; 113-126.

Caro Cuenca M, Hooper AJ, Hanssen RF. 2011. A new method for temporal phase unwrapping of persistent scatterers InSAR time series. IEEE Transactions on Geoscience and Remote Sensing 49(11): 4606-4615.

CHG. 2017. Sistema de información hidrológica de la Cuenca del Guadalquivir. (http://www.chguadalquivir.es/saih). Last Access: February 1, 2017.

Ciampalini A, Raspini F, Moretti S. 2015. Landslide back monitoring and forecasting by using PSInSAR technique: the case of Naso (Sicily, southern Italy). Atti della Società Toscana di Scienze Naturali, Memorie Serie A 122: 19-31 https://doi.org/10.2424/ASTSN.M.2015.16.

Cigna F, Novellino A, Jordan CJ, Sowter A, Ramondini M, Calcaterra D. 2014. Intermittent SBAS (ISBAS) InSAR with COSMO-SkyMed Xband high resolution SAR data for landslide inventory mapping in Piana degli Albanesi (Italy). Proceedings of the SPIE 9243, SAR Image Analysis, Modeling, and Techniques XIV, 92431B (October 22, 2014). https://doi.org/10.1117/12.2067424.

Colesanti C, Wasowski J. 2006. Investigating landslides with spaceborne Synthetic Aperture Radar (SAR) interferometry. Engineering Geology 88(3): 173-199.

Collantes de Terán F. 1977. Contribución al estudio de la topografía sevillana en la antigüedad y en la Edad Media. CSIC: Sevilla.

Davila-Hernandez N, Madrigal D, Expósito JL, Antonio X. 2014. Multitemporal analysis of land subsidence in Toluca valley (Mexico) through a combination of persistent interferometry (PSI) and historical piezometric data. Advances in Remote Sensing 3: 49-60 https://doi.org/10.4236/ars.2014.32005.

de Torres T. 1973. Mapa Geológico de España 1:50.000 MAGNA. Hoja $n^{\circ}$ 984, Sevilla. Instituto Geológico y Minero de España, Madrid.

del Moral Ituarte L. 1991. La obra hidráulica en la Cuenca Baja del Guadalquivir (Siglos XVIII-XX). Gestión del agua y organización del territorio. Universidad de Sevilla, Consejería de Obras Públicas y Transportes, Ministerio de Agricultura, Pesca y Alimentación (eds).

del Moral Ituarte L. 1997. El agua en la organización del espacio urbano: el caso de Sevilla y el Guadalquivir. Documents d'Análisi Geográfica 31: 117-127.

Del Ventisette C, Righini G, Moretti S, Casagli N. 2014. Multitemporal landslides inventory map updating using spaceborneSAR analysis. International Journal of Applied Earth Observation and Geoinformation 30: 238-246 https://doi.org/10.1016/j. jag.2014.02.008.

Díaz del Olmo F, Borja F. 1991. Aluvionamientos recientes en Andalucía occidental. Physio-Géo 22-23: 24-54.

Díaz del Olmo F, Vallespí E, Baena Escudero R, Recio JM. 1989. Terrazas Pleistocenas del Guadalquivir Occidental: Geomorfología, suelos, paleosuelos y secuencia cultural. In El Cuaternario en Andalucía Occidental, Acosta J, Alvarez G, Baena Escudero R, Borja Barrera F, Castiñeira J (eds), Vol. 1, AEQUA monografías: AEQUA (Sevilla). ISBN: 84-600-7270-3 33-42.

Durán-Valsero JJ, López-Geta JA, Martín-Machuca M, Maestre Acosta A, Pérez Martín P, Mora Fernández P. 2003. Atlas hidrogeológico de la provincia de Sevilla. IGME-Diputación Provincial de Sevilla: Madrid.

Ezquerro $P$, Herrera G, Marchamalo $M$, Tomás T, Béjar-Pizarro $M$, Martínez R. 2014. A quasic-elastic aquifer deformation behavior: Madrid aquifer case study. Journal of Hydrology 519: 1192-1204 https://doi.org/10.1016/j.jhydrol.214.08.040.

Ferretti A, Prati C, Rocca F. 2001. Permanent scatterers in SAR interferometry. IEEE Transactions on Geoscience and Remote Sensing 39(1): 8-20.

Frangioni S, Bianchini S, Moretti S. 2015. Landslide inventory updating by means of persistent scatterer interferometry (PSI): the Setta basin (Italy) case study. Geomatics Natural Hazards and Risk 6(5-7): 419-438 https://doi.org/10.1080/19475705.2013.866985.

Funning G), Barke RM, Lamb SH, Minaya E, Parsons B, Wright TJ. 2005. The 1998 Aiquile, Bolivia earthquake: a seismically active 
fault revealed with InSAR. Earth and Planetary Science Letters 232(1): $39-49$.

Gabriel AK, Goldstein RM, Zebker HA. 1989. Mapping small elevation changes over large areas: differential radar interferometry. Journal of Geophysical Research 94(B7): 9183-9191.

Galloway DL, Hoffmann J. 2007. The application of satellite differential SAR interferometry-derived ground displacements in hydrogeology. Hydrogeology Journal 15(1): 133-154 https://doi.org/10.1007/ s10040-006-0121-5.

Galloway DL, Jones DR, Ingebritsen SE. 1999. Land Subsidence in the United States. US Geological Survey Circular 1182, 177.

García B, Guerrero I, Baena R. 1999. La dinámica de meandros durante el Cuaternario reciente en la conformación de la llanura aluvial del Bajo Guadalquivir, aguas arriba de Sevilla. In Avances en el estudio del Cuaternario español, Roqué i Pau C. and Pallí Buxó, LI. (eds); Universitat de Girona Girona; 119-124.

Ghiglia DC, Pritt MD. 1998. Two-Dimensional Phase Unwrapping: Theory, Algorithms, and Software. Wiley: New York.

Goldstein RM, Werner CL. 1998. Radar interferogram filtering for geophysical applications. Geophysical Research Letters 25: 4035-4038.

Goy JL, Zazo C, Rodríguez-Vidal J. 1994. In Geomorfología de España (Gutiérrez-Elorza, Eds. coord.). Ed. Rueda: 123-159.

Gregory KJ. 1977. Channel and network metamorphosis in northern New South Wales. In River Channel Changes, Gregory KJ (ed). Wiley: Chichester

Gregory KJ. 1995. Human activity and palaeohydrology. In Global Continental Palaeohydrology, Gregory KJ, Starkel L, Baker VR (eds). Wiley: Chichester; 151-172.

Hanssen RF. 2001. Radar Interferometry: Data Interpretation and Error Analysis. Kluwer Academic Publishers: Dordrecht, The Netherlands.

Higgins SA, Overeem I, Steckler MS, Syvitski JP, Seeber L, Akhter SH. 2014. InSAR measurements of compaction and subsidence in the Ganges-Brahmaputra Delta, Bangladesh. Journal of Geophysical Research: Earth Surface 119(8): 1768-1781.

Holzer TL. 1984. Ground failure induced by groundwater withdrawal from unconsolidated sediment. Reviews in Engineering Geology 6: 67-105.

Hooke JM. 2006. Human impacts on fluvial systems in the Mediterranean region. Geomorphology 79: 311-335.

Hooper AJ. 2006. Persistent Scatterer Radar Interferometry for Crustal Deformation Studies and Modelling of Volcanic Deformation. PhD Thesis, Stanford University.

Hooper A. 2008. A multi-temporal InSAR method incorporating both persistent scatterer and small baseline approaches. Geophysical Research Letters (35) L16302. https://doi.org/10.1029/2008GL034654.

Hooper A. 2010. A statistical-cost approach to unwrapping the phase of InSAR time series. European Space Agency ESA SP-677 (Special publication). Frascati: Italy.

Hooper A, Segall P, Zebker H. 2007. Persistent scatterer InSAR for crustal deformation analysis, with application to Volcán Alcedo, Galápagos. Journal of Geophysical Research 112: B07407 https:// doi.org/10.1029/2006JB004763.

Hooper A, Zebker H, Segall P, Kampes B. 2004. A new method for measuring deformation on volcanoes and other natural terrains using InSAR persistent scatterers. Geophysical Research Letters 31 L23611. https://doi.org/10.1029/2004GL021737.

IGME. 1990. Mapa geotécnico para la Ordenación Territorial y Urbana de Sevilla. Scale 1:25000.

Kampes BM. 2006. Radar Interferometry: Persistent Scatterer Technique. Springer: Dordrecht, The Netherlands.

Ketelaar VBH, Gini G. 2009. Satellite Radar Interferometry, Subsidence Monitoring Techniques. Springer, Dordrecht, The Netherlands.

Mazzotti S, Lambert A, Van der Kooij M, Mainville A. 2009. Impact of anthropogenic subsidence on relative sea-level rise in the Fraser River delta. Geology 37(9): 771-774.

Meisina C, Zucca F, Notti D, Colombo A, Cucchi A, Savio G, Giannico C, Bianchi M. 2008. Geological interpretation of PSInSAR data at regional scale. Sensors 8(11): 7469-7492 https://doi.org/10.3390/s8117469.

Menanteau L. 1982. Les Marismas du Guadalquivir, exemple de transformation d'un paysage alluvial au cours du quaternaire récent. Université de Paris-Sorbone, U.E.R. de Géographie: Paris.

Menanteau L, Vanney JR. 1985. El cauce del Bajo Guadalquivir: morfología, hidrología y evolución histórica. In El Río. El Bajo Guadalquivir, Equipo 28 (ed). Ayuntamiento de Sevilla: Sevilla; 116-127.
Meinzer, O. E. 1928. Compressibility and elasticity of artesian aquifers. Economic Geology, 23(3): 263-291.

Miall AD. 1977. A review of the braided-river depositional environment. Earth-Science Reviews 13: 1-62.

Notti D, Herrera G, Bianchini S, Meisina C, García-Davalillo JC, Zucca F. 2014. A methodology for improving landslide PSI data analysis. International Journal of Remote Sensing 35(6): 2186-2214 https:// doi.org/10.1080/01431161.2014.889864.

Novellino A. 2015. Assessment of Landslide Susceptibility in Structurally Complex Formations by Integration of Different A-DInSAR Techniques. $\mathrm{PhD}$ thesis. Federico II University of Naples, Department of Earth, Environment and Resources Sciences, Naples, Italy.

Peyret M, Rolandone F, Dominguez S, Djamour Y, Meyer B. 2008. Source model for the Mw 6.1, 31 March 2006, Chalan-Chulan earthquake (Iran) from InSAR. Terra Nova 20(2): 126-133.

Poland JF (ed). 1984. Guidebook to Studies of Land Subsidence due to Ground-Water Withdrawal. v. 40 of UNESCO Studies and Reports in Hydrology: Paris, France, United Nations Educational, Scientific and Cultural Organization, 305, 5 appendixes.

Roldán García FJ, Borrero Domínguez J. 1988. Mapa Geológico de España 1:50.000 MAGNA. Hoja $n^{\circ}$ 985, Carmona. Instituto Geológico y Minero de España (eds), Madrid.

Rosen PA, Hensley S, Joughin IR, Li FK, Madsen SN, Rodriguez E, Goldstein RM. 2000. Synthetic aperture radar interferometry. Proceedings of IEEE 88(3): 333-382.

Ruiz-Constán A, Ruiz-Armenteros AM, Lamas-Fernández F, MartosRosillo S, Delgado JM, Bekaert DPS, Sousa JJ, Gil AJ, Caro Cuenca M, Hanssen RF, Galindo-Zaldívar J, Sanz de Galdeano C. 2016. Multi-temporal InSAR evidence of ground subsidence induced by groundwater withdrawal: the Montellano aquifer (SW Spain). Environmental Earth Sciences 75(3): 1-16.

Sousa J, Hooper A, Hanssen R, Bastos L, Ruiz A. 2011. Persistent scatterer InSAR: a comparison of methodologies based on a model of temporal deformation vs spatial correlation selection criteria. Remote Sensing of Environment 115(10): 2652-2663.

Sousa J, Ruiz A, Hanssen R, Bastos L, Gil A, Galindo-Zaldívar J, Sanz de Galdeano C. 2010. PS-InSAR processing methodologies in the detection of field surface deformation - study of the Granada Basin (Central Betic Cordilleras, Southern Spain). Journal of Geodynamics 49: 181-189 https://doi.org/10.1016/j.jog.2009.12.002.

Strahler AN. 1956. The nature of induced erosion and aggradation. In Man's Role in Changing the Face of the Earth, Thomas WL (ed). University of Chicago Press: Chicago; 621-638.

Stramondo S, Bozzano F, Marra F, Wegmuller U, Cinti FR, Moro M, Saroli M. 2008. Subsidence induced by urbanisation in the city of Rome detected by advanced InSAR technique and geotechnical investigations. Remote Sensing of Environment 112(6): 3160-3172.

Thomas WL, Jr. 1956. Man's Role in Changing the Face of the Earth. University Press: Chicago.

Tomás R, Herrera G, Cooksley G, Mulas J. 2011. Persistent scatterer interferometry subsidence data exploitation using spatial tools: the Vega Media of the Segura river basin case study. Journal of Hydrology 400(3): 411-428.

Tomás R, Romero R, Mulas J, Marturià JJ, Mallorquí JJ, Lopez-Sanchez JM, Herrera G, Gutiérrez F, González PJ, Fernández J, Duque S, Concha-Dimas A, Cocksley G, Castañeda C, Carrasco D, Blanco P. 2014. Radar interferometry techniques for the study of ground subsidence phenomena: a review of practical issues through cases in Spain. Environmental Earth Sciences 71: 163-181.

Uribelarrea D, Benito G. 2008. Fluvial changes of the Guadalquivir river during the Holocene in Córdoba (Southern Spain). Geomorphology 100: 14-31.

Vanney JR. 1970. L'hidrologie du Bas Guadalquivir. CSIC: Madrid; 175. Wolman MG. 1967. A cycle of sedimentation and erosion in urban river channels. Geografiska Annaler 49A: 385-395.

Wright VP, Marriott SB. 1993. The sequence stratigraphy of fluvial depositional systems: the role of floodplain sediment storage. Sedimentary Geology 86: 203-210.

Zhang JZ, Huang HJ, Bi HB. 2015. Land subsidence in the modern Yellow River Delta based on InSAR time series analysis. Natural Hazards 75(3): 2385-2397 https://doi.org/10.1007/s11069-0141434-7. 